University of Louisville

ThinkIR: The University of Louisville's Institutional Repository

Electronic Theses and Dissertations

$12-2007$

\title{
André Jeunet : expanded educational opportunities for a photographic exhibition.
}

Brian J. Davis 1958-

University of Louisville

Follow this and additional works at: https://ir.library.louisville.edu/etd

\section{Recommended Citation}

Davis, Brian J. 1958-, "André Jeunet : expanded educational opportunities for a photographic exhibition." (2007). Electronic Theses and Dissertations. Paper 321.

https://doi.org/10.18297/etd/321

This Master's Thesis is brought to you for free and open access by ThinkIR: The University of Louisville's Institutional Repository. It has been accepted for inclusion in Electronic Theses and Dissertations by an authorized administrator of ThinkIR: The University of Louisville's Institutional Repository. This title appears here courtesy of the author, who has retained all other copyrights. For more information, please contact thinkir@louisville.edu. 


\title{
“ANDRÉ JEUNET: APPLYING EDUCATIONAL THEORY AS A GUIDE FOR DEVELOPING A PHOTOGRAPHIC EXHIBITION"
}

\author{
By \\ Brian J. Davis \\ B.A., Ohio Wesleyan University, 1979 \\ A.A., Jefferson Community College, University of Kentucky, 1984 \\ A Thesis \\ Submitted to the Faculty of the \\ Graduate School of the University of Louisville \\ in Partial Fulfillment of the Requirements \\ for the Degree of
}

Master of Arts

Department of Fine Arts

University of Louisville

Louisville, Kentucky

December 2007 
Copyright 2007 by Brian J. Davis

All Rights Reserved 
“ANDRÉ JEUNET: APPLYING EDUCATIONAL THEORY AS A GUIDE FOR DEVELOPING A PHOTOGRAPHIC EXHIBITION”

\author{
By \\ Brian J. Davis \\ B.A., Ohio Wesleyan University, 1979 \\ A.A., Jefferson Community College, University of Kentucky, 1984
}

A Thesis Approved on

November 21, 2007

by the following Thesis Committee:

Thesis Director 


\section{DEDICATION}

This thesis is dedicated to Owsley Brown Frazier, a gentleman of vision and generosity

who made my return to the museum field possible and provided me the ability to grow personally and professionally, and to Walter “Chip” Karcheski, Jr.,

an incredible colleague, curator, mentor, and friend who helped make this project possible and whose influence will always be a guiding star. 


\section{ACKNOWLEDGMENTS}

I would probably never written a Master's thesis if not for my academic adviser and mentor, John Begley. His encouragement and support was instrumental in my decision to apply to graduate school and my ability to see this thesis to its conclusion.

My experience as cocurator of an exhibit of photographs by André Jeunet was the result of a wonderful collaboration with Vicki Niehaus, a member of the Technical Services Department of Ekstrom Library. Vicki’s love of archival work and interest in helping out in the Photographic Archives made the exhibit possible. The assistance of the Photographic Archive’s program assistant, Susan Knoer, and curator, James “Andy” Anderson, was crucial as well.

The best part of working on the Jeunet exhibit was getting to know, and having the pleasure working alongside members of André Jeunet’s family who helped bring the exhibit to fruition: Jeunet's daughter and son-in-law, Cécile and Richard Spalding; Richard Jeunet Spalding and his wife, Elizabeth Smigielski; Cynthia Amée Spalding; and Steven Spalding and his wife, Leslie Friesen, who also served as the project's graphic designer. Their knowledge, passion, and love of the photographs is a living testament to their family and their own strongly held beliefs in all that mankind has to offer that is creative, positive, and constructive. 


\section{ABSTRACT \\ ANDRÉ JEUNET: EXPANDED EDUCATIONAL OPPORTUNITIES \\ FOR A PHOTOGRAPHIC EXHIBITION}

Brian J. Davis

November 21, 2007

In spring 2006, the Frazier International History Museum, in conjunction with the Ekstrom Library Photographic Archives at the University of Louisville, mounted an exhibit of 47 photographs taken by a young French foot soldier during World War I. The exhibit, titled “André Jeunet: Images of WWI by a Pacifist Soldier,” ran from May 19 through September 4, 2006. The main concept behind the exhibit was to show images of World War I that focused less on the horrific aspects of combat and more of the everyday life the of common soldier, and to highlight that although many soldiers fought out of patriotism, some French soldiers held on to strong pacifist ideas. Another reason for mounting the show was to provide a public venue for these photographs, which contained strong artistic, historical, as well as sentimental value to Jeunet's family members. It would be a premiere of the images, since they had never been publicly displayed.

The exhibit, which I organized and cocurated as Head of Education at the Frazier International History Museum, with Vicki Niehaus, University of Louisville Ekstrom Library, Technical Services, by was assembled over the course of a year. A budget of approximately \$5,000, made possible by contributions from Joseph and Joseph 
Architects, Richard and Cécile Spalding, the Frazier Museum, and in-kind services from Framers Supply Company paid for materials and covered expenses for an opening reception.

My thesis focuses on the educational components of the exhibit, and the ways that educational opportunities could have been expanded and enhanced during the run of the exhibit and even after it ended.

This thesis will also explore ways that educational and cognitive theory can influence exhibit design and layout to maximize opportunities for learning. It is the author's belief that examining and looking for ways to enhance learning are central to the exhibition process. Facilitating visitors' ability to interact with and find meaning as they spend time in an exhibition environment encourages them to engage in activities such as reading, examining, exploring, comparing, and discussing. 


\section{LIST OF IMAGES}

André Jeunet: Early self-portrait...........................................2

Truck caravan to Verdun....................................................

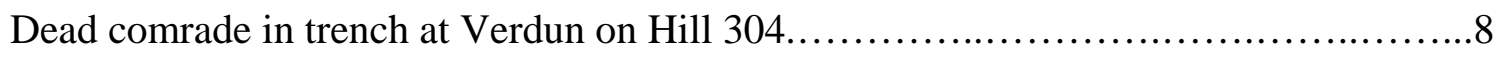

A ship heading to the eastern front............................................. 10

Jeunet exhibit opening reception............................................17

Entrance to Jeunet exhibit.................................................22

Floor plan of Jeunet exhibit................................................23

A view of the Jeunet exhibit.................................................26

Jeunet biography and introduction panel......................................28

Historical overview panel.................................................29

Jeunet's personal writings panel............................................30

Comrade and village kids in Balkans..........................................54 


\section{TABLE OF CONTENTS}

ACKNOWLEDGMENTS ....................................................

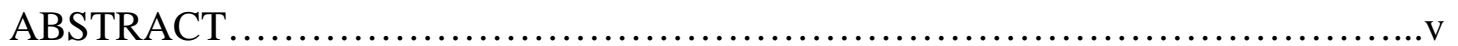

LIST OF IMAGES ..........................................................

\section{CHAPTER}

I. CREATING THE JEUNET EXHIBIT

History and Background of the Exhibit...................................

Images of War by a Pacifist Soldier...................................13

II. CREATING AN EXHIBIT TO FOCUS ON A CENTRALIZED THEME

Determining a Centralized Theme.........................................18

Using Layout to Enhance Educational Objectives............................20

Use of Text Panels to Highlight Themes and Objectives.......................25

III. INCORPORATING EDUCATIONAL THEORY

Educational Themes of Jeunet Exhibit..................................33

Using Educational Theory to Expand Learning Opportunities...................34

Practical Applications for Photographic Exhibitions..........................38

IV. USING TECHNOLOGY TO EXTEND THE EDUCATIONAL POTENTIAL OF AN EXHIBITION

Web-Based Technologies............................................48

Audio Tours and Podcasts..............................................50

Passive and Interactive Media.........................................51 
V. CONCLUSION: THOUGHTS AND REFLECTIONS

Assessment of Educational Objectives..........................................55

ENDNOTES

REFERENCES

APPENDICES

A) Wall Panels

B) Collection of Photographs

Jeunet Exhibit

Gallery and Exhibit Layout

Opening Reception

C) Gallery Handouts

D) Exhibit Promotional Materials

CURRICULUM VITAE 


\section{CHAPTER I}

\section{CREATING THE JEUNET EXHIBIT}

\section{History and Background of the Exhibit}

In the spring of 2005, I was fortunate enough to discover a series of photographs that was being accessioned and catalogued for the Ekstrom Library Photographic Archives at the University of Louisville. I was taking a museum methods course as part of my graduate studies, which required each student in the class to complete a special project. My classmate Vicki Niehaus was assisting the Photographic Archives with the accessioning of 210 negatives of photographs taken by André Jeunet, who served as a French infantry soldier during World War I (See figure 1). Jeunet’s daughter, Cécile Spalding, had donated her father's photographs to the Archives. When photocopies of some of the photographs were circulated in the class, I was astonished by the power and relevance the photographs held nearly ninety years after being taken.

I took the class while I was head of education at the Frazier International History Museum. Founded by Owsley Brown Frazier, philanthropist and former chairman of Brown Forman Distilleries, the museum opened in May 2003 in downtown Louisville. Initially branded as The Frazier Historical Arms Museum, the museum formed an agreement with the British Royal Armouries Museum in Leeds, to open a 


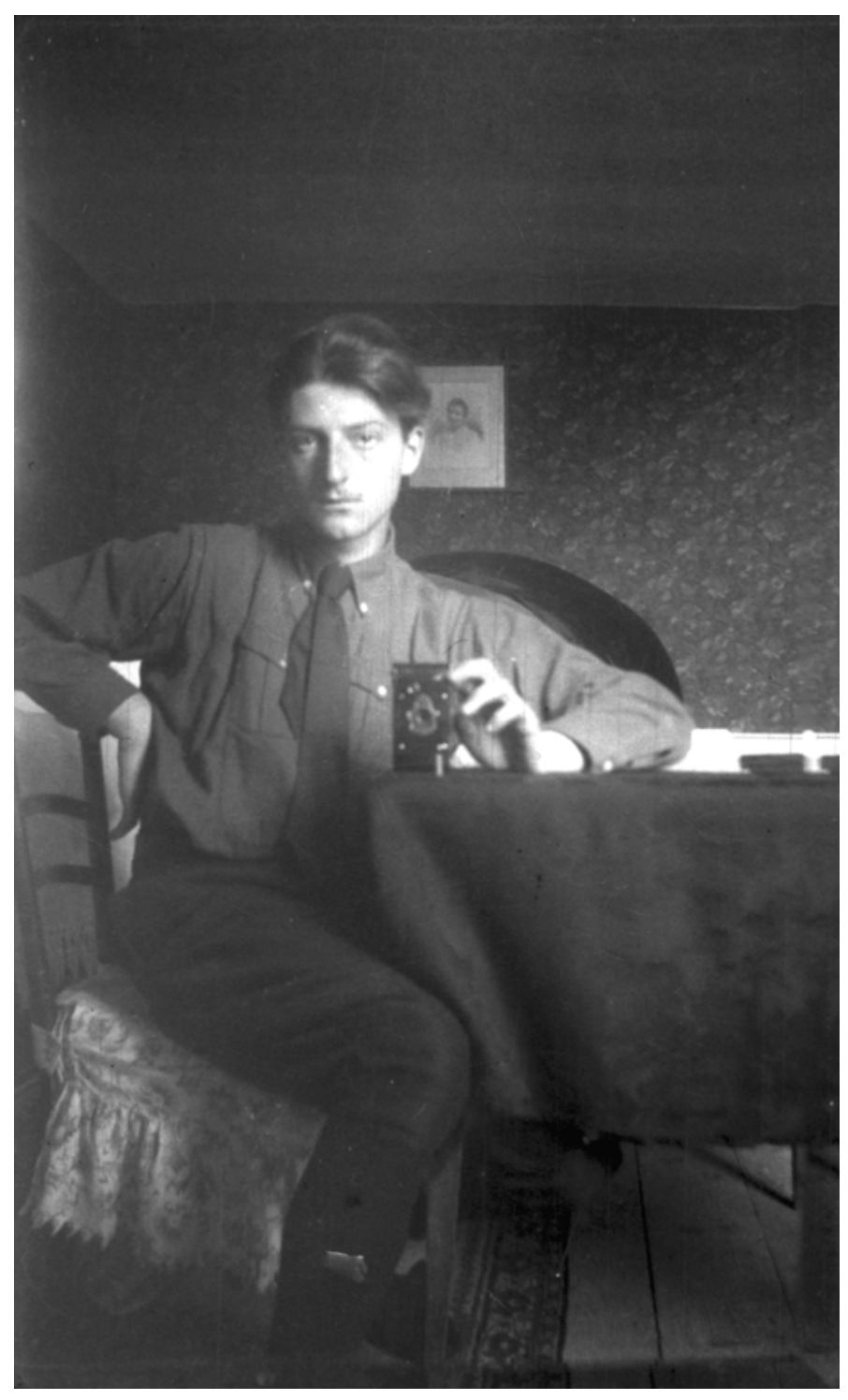

Figure 1. Early self-portrait of André Jeunet taken from a reflection in a large dresser mirror. From information provided by Jeunet’s family, this photograph was taken in Jougne, France, while Jeunet was on leave in September 1917. He was 21 years old at the time.

SOURCE: André Jeunet Collection, Special Collections Photographic Archives, University of Louisville. 
museum to portray history through the lens of arms and armor. Together they designed an exhibition whose content begins in the middle of the Medieval Period and ends at the beginning of the Twentieth Century. Although World War I is technically outside the historical period covered by the Frazier Museum, the photographs' unique story was in many ways timeless, and the potential for collaboration was enthralling.

The story behind the collection was also worth telling. Born in 1896, Jeunet was 18 when he was inducted into the French army. His pictures tell a story more of Jeunet than of World War I—of travels and comrades, of death as well as affirmations of life—and of a young man who wrote about his opposition to war in a personal diary and in letters to his family. There were numerous defectors and deserters in the French army, yet Jeunet served until the end, even facing a military court-martial at one point for his outspoken views.

I wanted to display Jeunet's photographs for the following reasons:

- Jeunet, like soldiers before and after him, managed to find and capture moments of true beauty and humanity in the mist of chaos and destruction.

- Throughout history, fighting men resisted war and military service and expressed antiwar sentiments in the letters and other personal writings.

- Technology in the early $20^{\text {th }}$ century transformed photography into an art form that was readily accessible, portable, and affordable.

- All wars have lasting repercussions socially, technologically, politically, and culturally, often leaving unresolved issues that can simmer for decades, resulting in future conflict(s). 
These themes will be addressed more fully in chapter two related to the importance of creating a centralized theme and its effect on educational goals and interpretation; however, I also wanted to focus on the images aesthetically, as well as to take advantage of photography's inherent ability to make social and political statements. These simultaneous goals guided me in selecting the images that were ultimately selected for the exhibit.

I felt the photographs would create a compelling exhibit because they contained a unique quality. They emanated Jeunet’s inherent artistic qualities, which would later mature during his training as an architect and become obvious in his architectural renderings, and they captured a unique view of World War I. His wartime photographs possessed a quiet strength, powerful but lacking the type of bravado or "in-your-face" attributes that photographs taken by military staff photographers or photojournalists emanate. (I often see photographic exhibits that make those statements of aesthetics and a social message separately, and I think that more successful exhibits include both elements.) I felt the photographs would create an exhibit that featured not only images that were visually arresting, but that told a compelling story.

I also wanted to present the photographs in a way that those who saw the exhibit might feel the same emotional and aesthetic impact that I felt on my first viewing the images. I found the photographs intriguing for two reasons: they are hauntingly beautiful and imbued with a melancholy that has a timeless quality; and they contain a strong voice with a strong affirmation of life, even in the midst of death and destruction. 
These considerations led me to select from among the 210 photographs a group that contained narrative qualities so the exhibit could help tell Jeunet's story. The exhibit eventually was organized into five groupings:

- Two self-portraits, a biographical panel, and the exhibit title in the form of a wall stencil forming an introduction to the gallery and the exhibit.

- A selection of photographs taken early in the war during Jeunet's time with the $139^{\text {th }}$ infantry regiment at the western front and specifically at the Battle of Verdun.

- Photographs from Jeunet's reassignment to the eastern front and his experiences in the Balkans with the $34^{\text {th }}$ colonial regiment, including time spent at Monastir, Albania (now Bitola, Macedonia).

- Two later self-portraits — one taken near the end of the war and one taken after the war, along with a wall panel of Jeunet's writings.

- A selection of images taken during Jeunet’s early training and several others were probably from the early part of war. These shots lined a brick wall leading from the back of the gallery to the entrance.

The photographs were loosely grouped chronologically and thematically. This enabled me to accommodate both aesthetic and narrative considerations. Input from Richard and Cécile Spalding was also taken into consideration. They requested that six of the original selections be replaced by other images. The alternate photographs reduced redundancy and presented stronger images that were better quality. 
A year after the exhibit opening, I continued to review materials to help piece together Jeunet’s story more fully. Despite lacking direct access to French military records, I found resources on the Internet and in libraries that fill in some of the details of Jeunet's experiences and travels during World War I.

André Jeunet attended training camp in the Picard region before serving on the western front, including seeing action at the Battle of Verdun and the Somme. From his photographs, it appears that early in the war he worked the supply lines to Verdun. He drove or helped load and unload the trucks that traveled nearly 24-hours-a-day, shuttling food, supplies, the wounded, and fresh troops to and from the front lines. One picture (see figure 2) shows him tired and dirty during a break in the driving.

John Keegan, in his book The First World War, describes the supply route to Verdun:

Behind Verdun, the single road that led to Bar-le-Duc fifty miles away was designated a supply route for trucks alone; 3,500 were assembled to bring forward the 2,000 tons of stores the garrison needed daily, the troops being ordered to march up and down the roadside fields. Any truck that broke down was pushed off the road, lest it interrupt the day-and-night flow of traffic. A whole division of Territorials was employed in road repairs and France was scoured for additional transport. Eventually 12,000 trucks would be used on what became known as the Voie sacrée [sacred way/avenue]. ${ }^{1}$

Jeunet photographed only one fatally wounded soldier at Verdun (see figure 3) which may have been a conscious decision or due to his experience at the front. The offensive by the Germans began in February of 1916. By the end of June, over 200,000 men on both sides had been killed. ${ }^{2}$ High casualties were the result of brutal assaults by the newly invented and very effective machine gun, bombardment from the largest and most sophisticated artillery ever developed, and a new weapon in the form of an improved chlorine gas. Sometime between 1916 and 1917, Jeunet was summoned before 


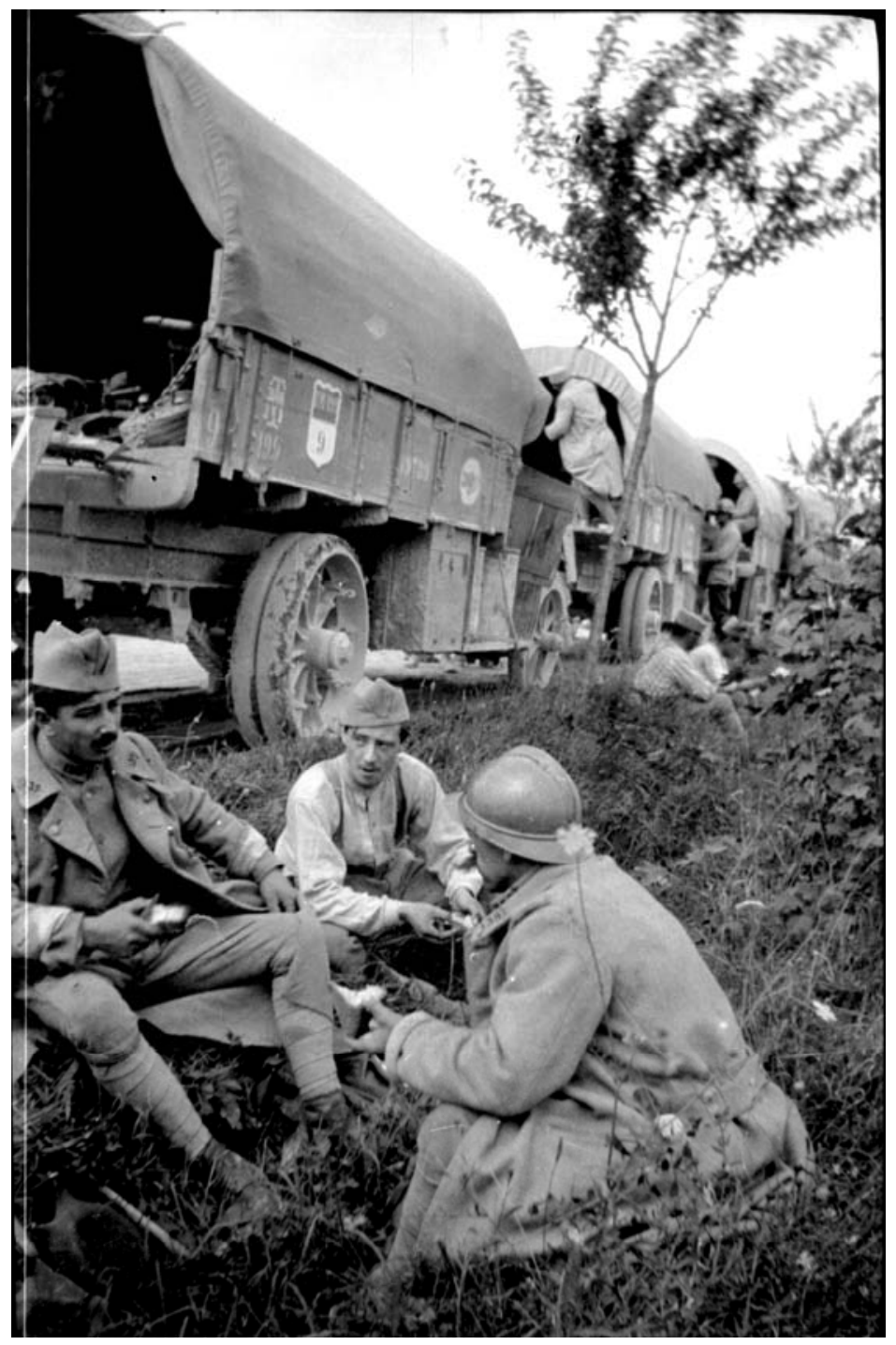

Figure 2. Jeunet (center) working as part of a truck convoy, probably delivering supplies to the front lines at Verdun. Closer inspection shows Jeunet holding a cable in his right hand to take the photograph. An examination of the insignia on the collar of the soldier on the left confirms that Jeunet was part of the 139e Régiment d’Infanterie.

SOURCE: André Jeunet Collection, Special Collections Photographic Archives, University of Louisville. 


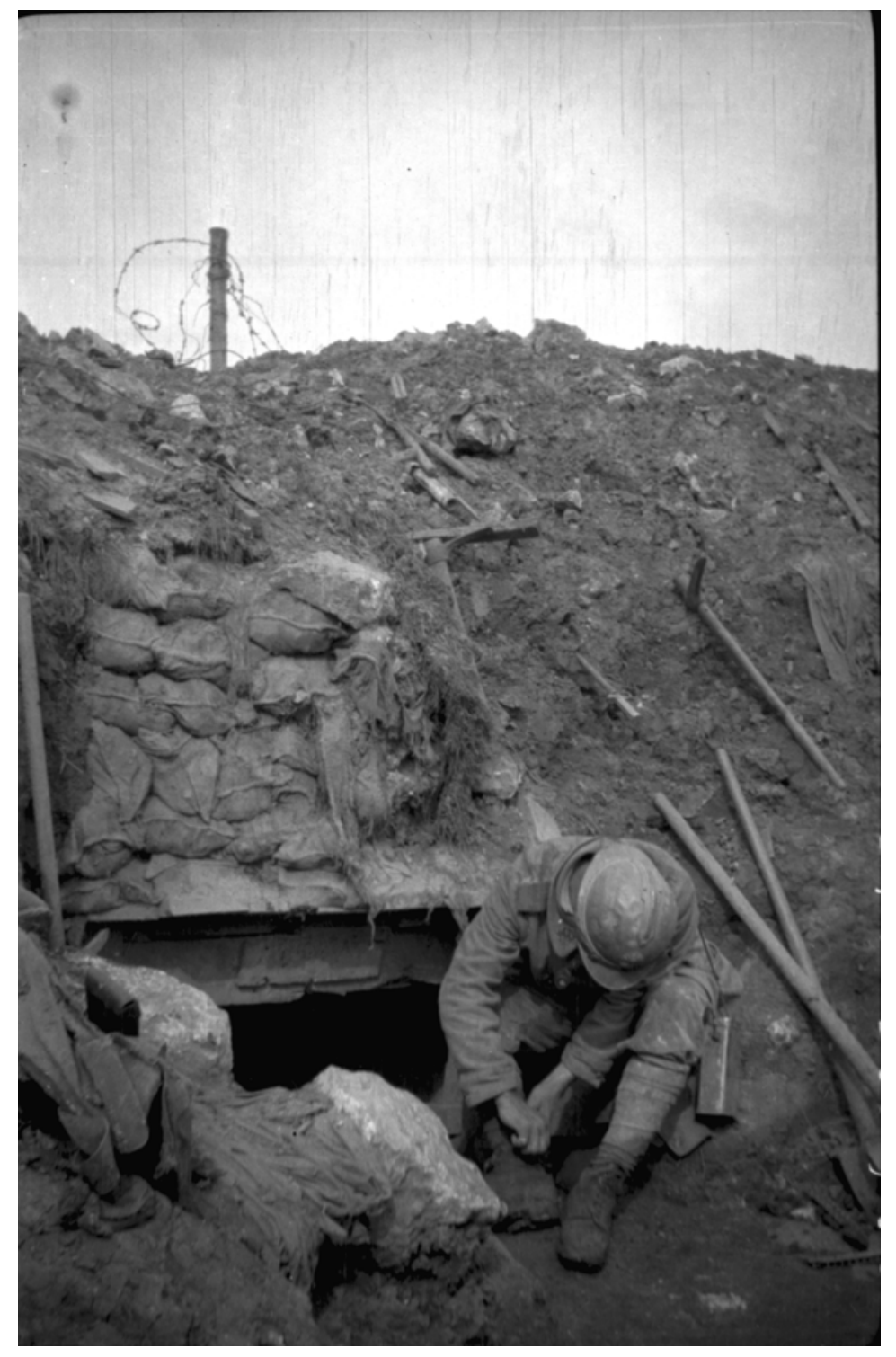

Figure 3. This is the only image of a casualty in Jeunet's collection. Although the soldier looks as if he is resting or tying his shoe, he is actually a victim of shrapnel on Côte (Hill) 304 at Verdun.

SOURCE: André Jeunet Collection, Special Collections Photographic Archives, University of Louisville. 
a court-martial to face charges related to his antiwar opinions. This took place during the buildup to the famous rebellions of French soldiers at the western front in reaction to the incredible carnage, which was blamed on the French generals' overall incompetence and poor command abilities.

Jeunet was among many French soldiers who saw themselves as socialists with antiwar or pacifist leanings who met similar fates of court-martials leading to reassignment, incarceration, and in some cases, corporal punishment. By monitoring conversations at the front and intercepting letters by army censors, the French government was well aware of the simmering caldron of discontent that would eventually erupt. (PBS Website, Censorship Letters) Even after a near-brush with a court-martial and a possible appointment with a firing squad, Jeunet was pulled from duty on the western front and shipped off across the Adriatic Sea to the Balkans (see figure 4) where he finds himself in 1917 as part of the Salonika Campaign in Northern Greece and Southern Serbia. Together, the French and British, with help from the Serbians, Russians and Italians, launched a savage offensive against Bulgaria in a desperate attempt to save Serbian and Albanian territory while trying to break the Austro-Ottoman alliance.

Even the story of how the images came to be part of the University of Louisville Photographic Archives is tied to Jeunet's fate. In Paris in 1945, Jeunet's only child, Cécile, met Richard Spalding, a young American serving with the U.S. Air Force. A native of Louisville, Richard returned to France after the war in 1948 to study music and to pursue his relationship with Cécile. The two were married in Paris and returned to settle in Louisville in 1949. Richard would eventually teach music as a professor at the University of Louisville. As a result of his trips to Louisville to visit his daughter, Jeunet 


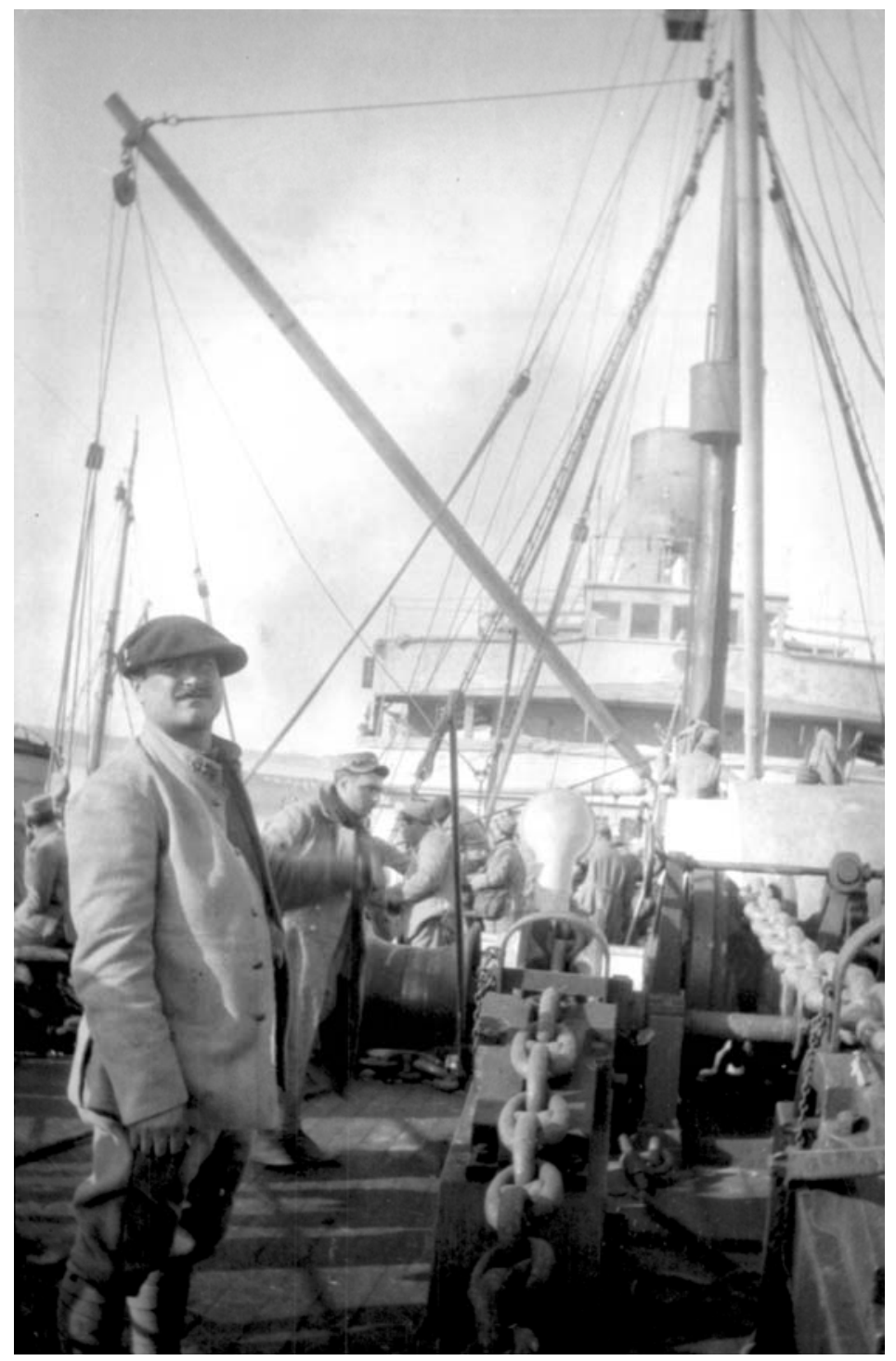

Figure 4. On board the Cateau-Renault in 1917, which carried Jeunet to the

Balkans. The ship left an Italian port and made a night crossing to Itea in Greece. A fellow soldier, pictured in the foreground, wears a regimental coat and beret. In his personal papers, Jeunet wrote about a submarine attack and the sinking of one of the ships in the convoy as it headed across the Adriatic Sea.

SOURCE: André Jeunet Collection, Special Collections Photographic Archives, University of Louisville 
and his wife Aimée immigrated to America in 1958. They lived in Louisville their remaining years.

The photographs that made up the Jeunet exhibit were printed from digital scans of the original negatives. The mere fact that Jeunet's negatives survived through two world wars and ended up with the Spaldings was amazing enough; yet, the Spaldings held on to 210 delicate — and in a few cases, faded negatives — until they decided to donate them to the Photographic Archives at the University of Louisville. When I discovered that the images had never been on public display, I decided to talk to both the curator and executive director at the Frazier Museum to see about presenting some of the photographs as part of my master’s degree work in critical and curatorial studies.

Although Vicki Niehaus and I discussed the possibilities during the spring of 2005, it would eventually take an entire year to mount the show. Among other things, there was the need to finish accessioning the collection, select final images, raise money for the exhibit and the opening reception, research and write wall panels, design the show, and locate the best venue within the museum.

By June of 2005, the entire Jeunet collection had been accessioned and Vicki had begun scanning the negatives and burning the digitized images to CDs. She began spending time with Jeunet's family, collecting information, conducting interviews, and documenting as much information as possible about Jeunet himself, the images, and their history.

By September, the Frazier's curator and my closest colleague, Walter "Chip” Karcheski, had reviewed the images and initially selected 37 . That number would 
eventually grow to 47 as I began to formulate ideas about the show and sought input from Vicki as well as Cécile and Richard Spalding.

By November of 2005 the planning was picking up momentum, and we continued to work on preliminary selection of images and research. In January of 2006 we began assembling the early collections of text that would later comprise the main wall panels. That process was hindered when Chip, went on medical leave from the museum. Having an extensive knowledge of military history, he had been helping me assemble the information we would use to develop labels and write text for the wall panels.

Although Chip’s illness slowed the planning process, Vicki and I continued to move forward, and in early February we had a small set of test prints made to see if the digital scans of the negative were of sufficient quality to use in the production of the final prints. By the end of February, we determined that the digital scans were acceptable enough, and we developed an exhibit concept. The initial title of the exhibit was “André Jeunet: A Foot Soldier's View of WWI.”

By the early part of March 2006 we secured corporate sponsorship for the exhibit and the opening reception. The architectural firm of Joseph and Joseph, for whom Jeunet had worked after immigrating to the United States, agreed to support the project. We began to have the digital scans cropped, printed, and prepared for framing. By this point we had also begun to seek input from the Spaldings in the selection of the images, and Vicki set up a meeting the last week of March to finalize selections and review all the text. 


\section{Images of War by a Pacifist Soldier}

It would take the eventual involvement of the photographer's family to bring meaning and a focus to the exhibit. That focus became apparent once Cécile, Jeunet's daughter, and Richard Spalding began proofreading the exhibit text and providing translations of several of Jeunet's wartime letters and journal entries. It was then that a main theme for the show began to emerge.

In his letters home and to his family, Jeunet remained a steadfast pacifist and a skeptic of war as a means to resolve conflict. Although space and other factors limited Jeunet's writings presented in the exhibit, the Spaldings' translations of several of Jeunet's letters helped us highlight the photographer's passion for life and distain for war. In a letter written between December 1944 and January 1945, Jeunet remains adamant in his feelings when he writes to a cousin.

Besides, I am still a stanch pacifist and I hate war as much as I hate the army, which is the instrument of war. I served in the army from 1914 to 1918 as an impenitent objector and my childlike honesty (I was barely twenty years old!) caused me to just miss being executed after being found guilty in a military court. I owe my life only to the wise, kind nature, and to the fatherly attitude of a "good" general whom I have always regretted having to count among the detested military. At that time I had the rare moral support, but how solid, of a man who died only a few days ago and whose name is Romain Rolland...I know... Much has changed since then: not I! I suppose I failed to adapt to circumstances, or was it supreme wisdom? ${ }^{3}$

Even after his years as a soldier during World War I, Jeunet show in his letters a strong conviction and moral compass that would remain consistent throughout his life. Vicki and I realized that Jeunet's writing would serve as the binding for the exhibit. The photographs told a story of their own, but Jeunet's passion poured out from his letters. In 
a letter written by Jeunet in Paris on August 19, 1954, to his daughter and son-in-law, his abhorrence of war is still potent and vehement.

My greatest act of gratitude remains having endured, during four years of World War I, that unspeakable horror! It was there that the spirit of the seeker and idealist was strengthened in me, a spirit that could be born solely out of a great misery suffered in common with others, and I have knowingly not limited them to my countrymen. ${ }^{4}$ (Jeunet, personal papers)

The photographs provide a direct connection to the situation and draw one in to Jeunet's world at a set time and place in history; however, Jeunet's written reflections contain a much more universal and timeless quality. His images document a world that no longer exists, but together, the photographs and his writings provide a damning indictment of a civilization that stubbornly refuses to learn from its mistakes. Inherent in the show is the tension and conflict contained within a man who felt obligated to defend his country, yet vehemently disagreed with society’s military response.

With a renewed focus, and the active participation of the Spaldings in helping finalize the materials, we completed the text for the exhibit. The time had arrived to design wall panels and develop promotional materials.

The theory of six degrees of separation may exist in other places, but in Louisville it is probably no more than three. Leslie Friesen, a professor of design and commercial art at the University of Louisville and one of the Spalding daughters-in-law, had heard about the plans for the exhibit. Agreeing to do the design work pro bono, she quickly got started on the conceptualization and layout of the text panels, an opening reception postcard, and several simple labels. 
One of the challenges of acting as curator was providing definitive information about when and where the photos were taken. I had done considerable research but hoped that Chip Karcheski would be able to assist me in analyzing some of the photos and provide additional detail. Unfortunately, Chip’s condition prevented his further involvement in the project. However, the exhibit already had enough momentum to keep it moving forward, and I would make due with the existing information we had already compiled.

Over the next few weeks all the prints were matted and framed, the exhibit opening date set (May 18, 2006), invitation list for the opening assembled, and both in-kind and cash donations secured to cover the exhibit's remaining costs. It was also during April that we decided to rename the exhibit "André Jeunet: Images of WWI by a Pacifist Soldier."

The title change helped to unify the entire project visually, thematically, and educationally. The theme of a pacifist soldier provided the show with the perfect oxymoron to capture the complexity of Jeunet as he struggled to justify his role, all contained within the images. It would have been easy to make the point that "war is hell" by showing images of death and carnage. The challenge was to tell a story about a man who captured another side of war — the everyday, mundane aspects—and to reveal the personal beliefs that guided his actions, and in turn, the lens of his camera.

By the end of April all the images had been printed and framed, and were stored at the Frazier Museum, ready for hanging, and by early May wall panels had been designed and most of the artwork was ready for production. I settled on using three panels: a biography of Jeunet, background information on World War I, and selections from his 
letters highlighting his pacifist views. The original panels were small, and the biography information alone took up three panels. By enlarging the panels to approximately 2'x3', we were able to include a map and time line with the World War I information and to fit all the biographical information down to a single panel. The job of determining placement of the images would have to wait until just before the opening, due to ongoing construction and painting in preparing the exhibit space.

The show opened with about 120 people attending. The entire Spalding family was able to see photographs printed from digital scans of negatives that had sat in a drawer for decades. Many attendees did not know the Spaldings or André Jeunet; however, there were friends, work associates, and family members who shared stories about Jeunet and reminisced about the years he lived in Louisville (see figure 5). 


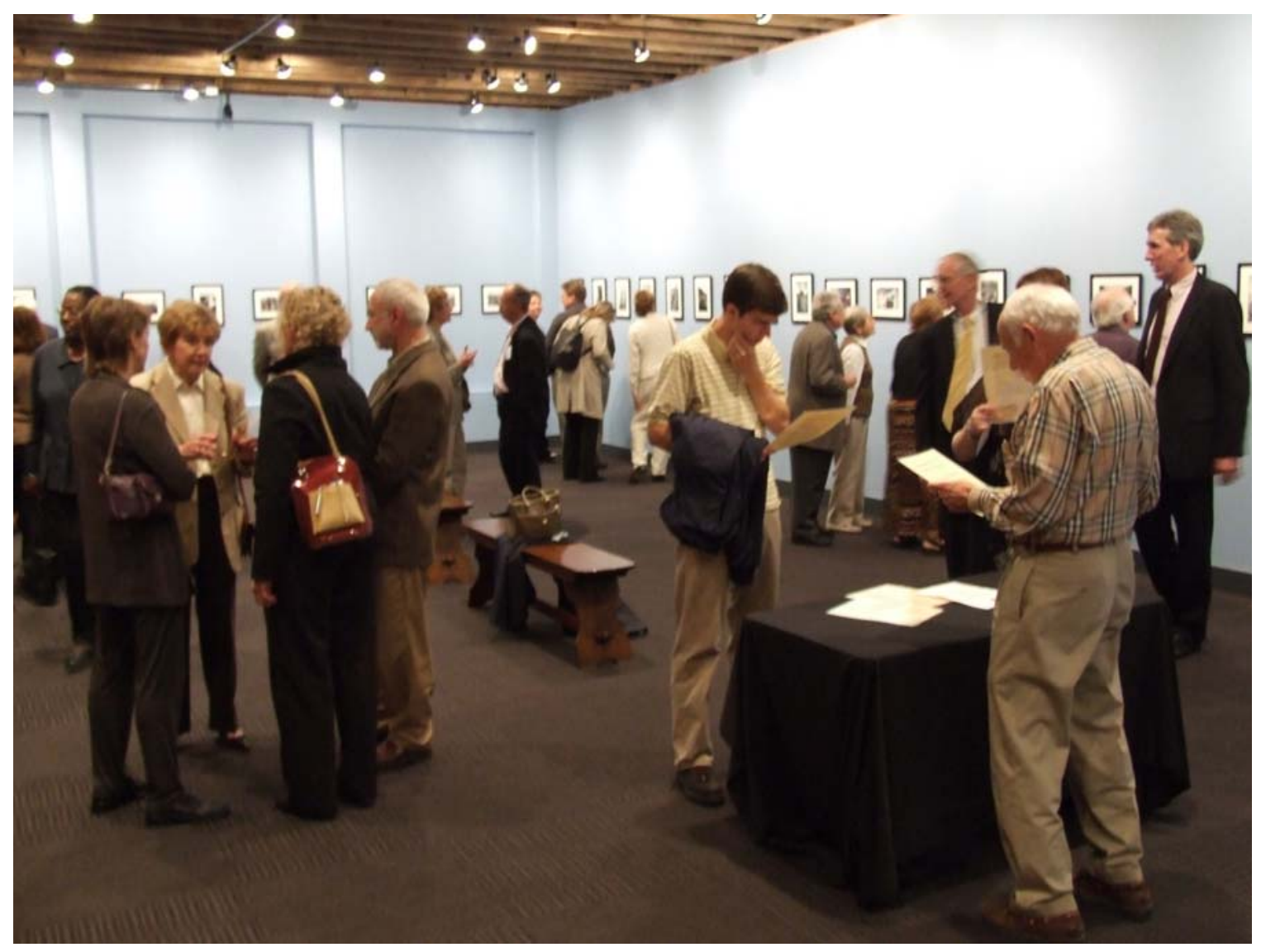

Figure 5. Jeunet Exhibit Opening Reception. Approximately 120 people attended the opening reception on May 8, 2005.

SOURCE: Photograph by author. 


\title{
CHAPTER II
}

\section{CREATING AN EXHIBIT TO FOCUS ON A CENTRALIZED THEME}

\author{
Determining a Centralized Theme
}

A powerful exhibition idea will clarify, limit, and focus the nature and scope of an exhibition and provide a well-defined goal against which to rate its success. ${ }^{4}$

Beverly Serrell opens her book Exhibit Labels: An Interpretive Approach with a discussion of the importance of giving exhibits one centralized theme-something she terms “The Big Idea.” I realized that the exhibit would be limited in its capacity for an extended narrative, so a primary focus would be essential. There was no way we would be able to adequately explain such a complex historical event as World War I. Changing the exhibit title allowed us to concentrate on Jeunet and his story. The danger of too broad a theme might result in an exhibit that is incoherent, rambling, or dull.

Having a big idea does not make visitors' experiences in the exhibition more controlled, constricted, or less open-ended than an exhibition without one, but it does increase the likelihood that visitors will be able to decipher the exhibition's communication goals. A big idea keeps the exhibit team accountable to their educational objectives while allowing visitors to construct their own experiences freely. ${ }^{5}$ 
The theme of the pacifist soldier allowed us to focus on Jeunet, an idealistic and passionate young man who had to balance his humanistic and poetic sensibilities with the horrendous realities of death and incomprehensible destruction. This theme was highlighted in the text panel containing excerpts from Jeunet's personal diary:

September 20, 1916. I am 20 years old! We are at war! The 'Great War' as future historians will say and before its crown will be toppled by the next 'last war'...I am 20 years old! And one cannot perceive the end of the massacre, which has already lasted two years. I am 20 years old and have only before my eyes the horrible spectacle of death. No more leaves, no more flowers, no more animals, even no more grass on the soil...this hilly and muddy ocean engulfs everything - even our souls, without light, and without joy. September 16, 1916! I am 20 years old, but my body is covered with vermin and my spirit is eaten by doubts. ${ }^{6}$

Jeunet's antiwar opinions and strong socialist and pacifist leanings led to a courtmartial, where he was saved from a firing squad only by the intervention of an officer he described as a "good general." However, similar sentiments held by other French soldiers led to large-scale mutinies by 1917.

In 1917, after the loss of millions of live, the stalemate on the front lines, and the disruption of nearly every aspect of daily life in all the combatant nations, many people - civilians and soldiers alike - still wanted to continue fighting to victory. The combatant nations rejected all the peace initiatives that were proposed in 1917. As the months passed, however, people on both sides of the conflict began to question the violence and massive slaughter. People everywhere sought ways to cope with, if not escape, the environment of war. Russian front line soldiers grew increasingly disillusioned and apathetic. Many refused to obey orders, retreating when commanded to advance; they deserted the military and engage in open rebellion and mass mutiny. In France, a failed offensive in the spring of 1917 resulted in a mutiny not against the war but against the way it was waged by the general staff. ${ }^{7}$

The power of his photographs documents a soldier that, while adamantly opposed to war, remained a steadfast patriot. In spite of his personal views and perhaps 
understanding the repercussions to loosing the war, Jeunet continued to serve his country until the armistice was signed on November 11, 1918.

\section{$\underline{\text { Using Layout to Enhance Educational Objectives }}$}

Although the exhibit addressed specific events in Jeunet's life and wartime experiences, its guiding theme helped determine image selection, layout, and placement. I tried to organize the photographs so that they would address the horrors of war, yet I wanted to concentrate more on Jeunet's view of war and present the photos as what they are- a very personal collection of one person's experiences that provides the visitor a means of interpreting the past.

For the exhibit to be presented in a coherent manner, photo placement would be crucial in helping to tell the story and emphasizing Jeunet’s artistic and humanitarian attributes. The room designated for the exhibit was originally an unfinished storage area being prepared as extra exhibit and meeting space. Therefore, it provided us the opportunity to paint the walls the same shade of horizon blue that the French infantry wore in Europe from 1915 to the end of the war.

The construction schedule allowed two days prior to the opening for hanging the show and to determine the layout and positions of the images. To save time, I could have printed out small versions of the images and built a model of the space to begin determining placement and layout of the show. Without the benefit of a model, I used the dimensions of the room to determine a basic layout. The room was very long, with a narrowed entrance (see figure 6). The entrance provided a way to use the biographical 
panel and two self-portraits to create an introduction. It also allowed for the title of the show to be placed above those images in the form of a vinyl stencil establishing the identity and atmosphere of the exhibit.

With only three large text panels to anchor the images, I knew I would use one panel for the introductory biographical text, one panel in the middle of the room to briefly discuss World War I, and a panel of Jeunet's writings would be placed at the far end of the room, since his words, "We are at war! I am twenty years old!" served as a large headline and was designed to be visible from the entrance in order to draw visitors into the gallery. In America, most people have a tendency to turn right after entering a room, so the photographs wrapped around the corner to the right to create a natural flow and pattern to the exhibit. To figure out the photograph’s exact placement, we took all the photographs out and sat them on the floor. Then we began placing them against the wall where I thought they should be hung. In order to tell a story, the photographs were organize in what I thought was chronological order, using two of the earlier self-portraits at the entrance with the biographical panel and two of the later self-portraits at the back wall next to the panel with Jeunet’s diary excerpts. I then used the World War I background panel to divide those photographs taken at the western front (Verdun and Somme) from those taken as part of his later participation at the eastern front. In his letters, Jeunet wrote of crossing the Adriatic Sea and landing in the port city of Itea, Greece, as part of the Salonika campaign in northern Greece and later finding himself in Monastir in southern Serbia (now Bitola in Macedonia). 


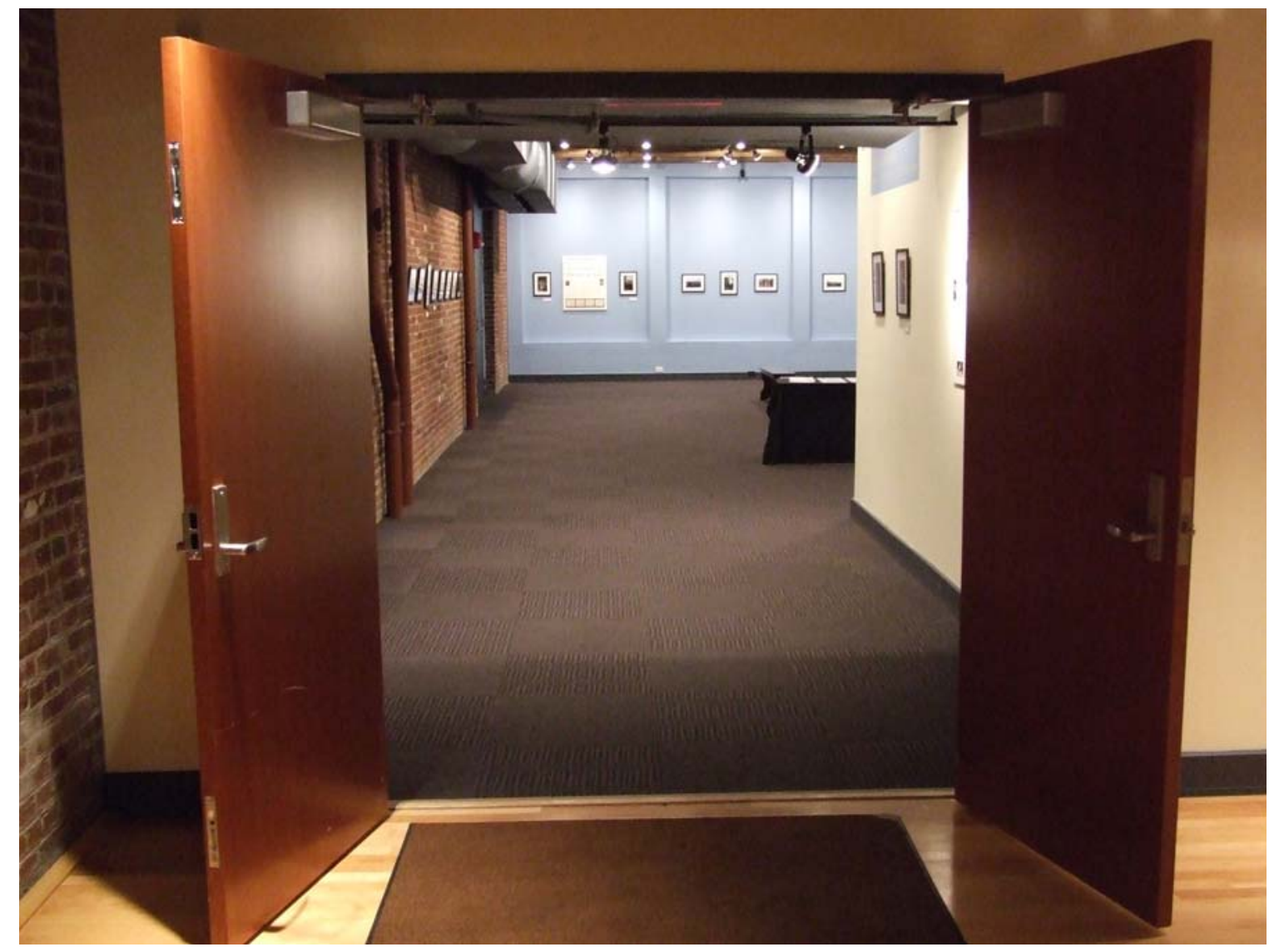

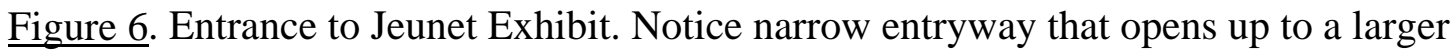
room. Window wells are along the back wall with a brick wall on the left. The introduction and biographical panel and exhibit title are to the right of the entry. In the immediate background is the panel with excerpts from Jeunet's diaries and letters. The heading “September 20, 1916 I am 20 years old! We are at war!” was designed as a large headline and helped to draw visitors into the gallery.

SOURCE: Photograph by author. 


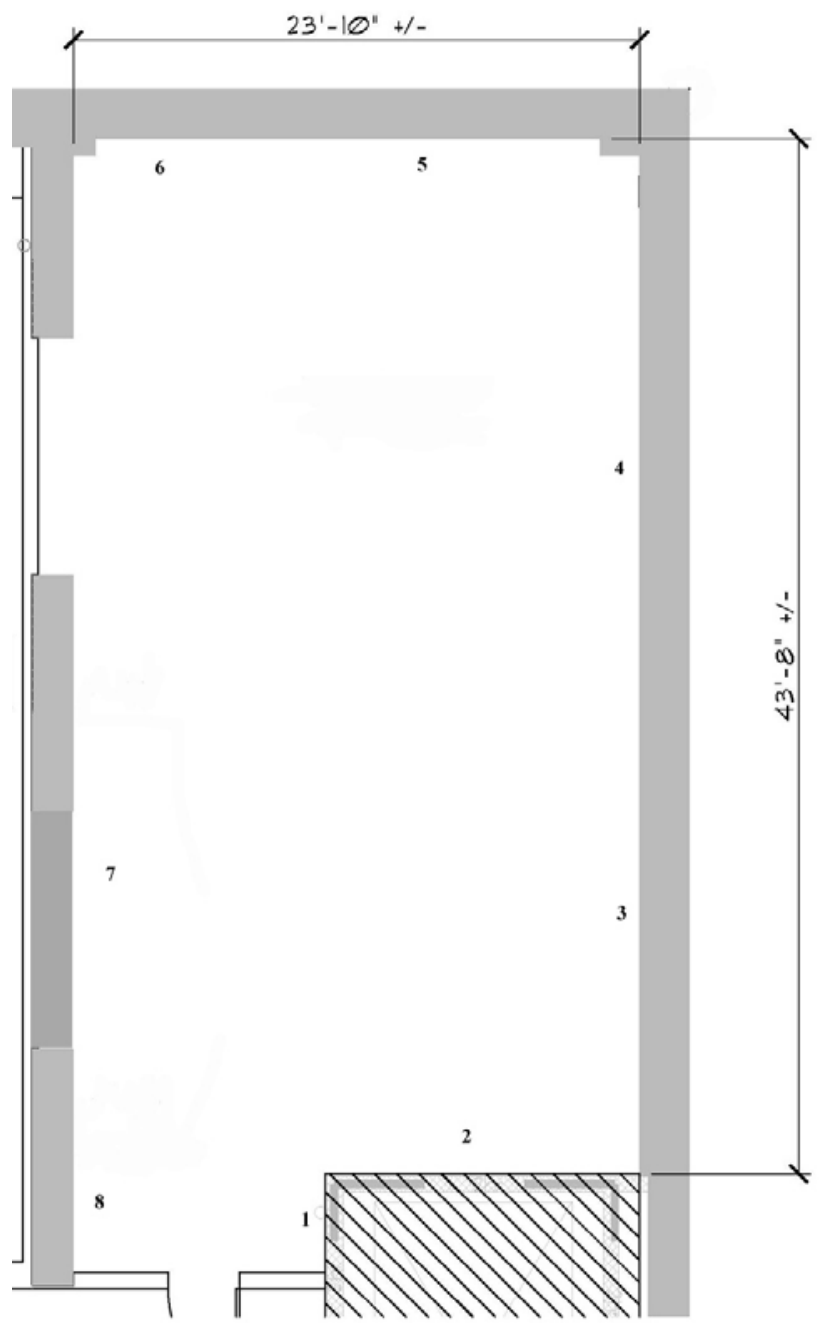

Figure 7. Floor plan of Jeunet Exhibit. This floor plan helps to illustrate the layout of the exhibit. 1) Exhibit title, two early self portraits and the Jeunet biography wall panel; 2) Photos of the Western Front including Verdun; 3) More images from the Western Front and the "France and World War One” wall panel; 4) Images from Jeunet’s journey to the Eastern Front and through the Balkans; 5) Images of the Balkans; 6) Two later self portraits and the wall panel containing excerpts from Jeunet’s letters and diary; 7) Miscellaneous photos including Jeunet’s basic training; 8) Thank you and acknowledgement panel.

SOURCE: Frazier International History Museum (modified by author) 
André Jeunet reminisced about his crossing of the Adriatic in the following lines he wrote to his daughter, Cécile, from Paris on January 27, 1952, before he and his wife took a steamship bound for the United States:

I think that I will not be sea-sick on the trip because I was not (sick) in 1917 during the night crossing of the Adriatic Sea in bad weather on a small ship, the Chateau-Renault, weighing hardly 15,000 tons. What is more, there was that terrible fear of the submarines, which didn't help matters! The ship behind ours was torpedoed in the Gulf of Corinth and sank. No victims other than the mechanics killed by the explosion of the torpedo in the machine room, and in addition, the rescued persons got a one-month leave of absence. I wasn't so lucky.....if you can call it that! ${ }^{8}$

A series of other photographs that included his basic training (possibly in Autun, approximately 85 kilometers southeast of Dijon) and several images that lacked specific information regarding the time or location were grouped together along a brick wall near the entrance to the gallery. The layout was not ideal, due to limited wall space and lack of specific information for many of the images, yet the final layout managed to create a flow and sense of story (see figures $7 \& 8$ ).

An exhibit's layout also helps to address both overt and underlying themes. The curator is able to direct viewers to specific images in a certain order to emphasize independent ideas or to build momentum based on aspects of the photographs as well as comparisons and similarities among the images. Some curators choose to influence this process by dividing an exhibit into thematic areas. By doing so, the curator is able to highlight themes and comparisons in text panels and the exhibit's narrative.

Since the narrative in the Jeunet exhibit was limited, I decided to not carry on a verbose discussion with viewers. I relied on the strength of the images themselves to communicate something about Jeunet, his artistic qualities, and the real-life situations 
found within his photographs. Once the photographs were hung on the wall, with the three large wall panels acting as spacers and interpretive devices between the thematic sections, I felt that the exhibit was effective in presenting Jeunet's wartime dilemma. Here was a dreamer and an artist, as well as an avid socialist and pacifist, surrounded by a horrific world of destruction and death. There were images of trench warfare and life at the western front, yet most of his photographs capture a tranquil and sometimes playful side of war: Jeunet horsing around with his comrades, scenic landscapes, small children in a rural village, mundane work tasks, or reflective self-portraits.

\section{Use of Text Panels to Highlight Themes and Objectives}

The three wall panels did a sufficient job of supporting several objectives:

1. Provide the introduction, context, and commentary to help interpret the photographs and provide thematic cohesion.

2. Break up the images into several distinct groupings.

3. Introduce additional images, graphics, and information to strengthen educational and contextual objectives.

The opening panel contained biographical information and helped set the stage for the exhibit and provide enough background information so that visitors would understand the context of the exhibit (see figure 9). The panel on France and World War I discussed the conditions that led to the war and France's role in the conflict. It also included a 1914 color-coded map of Europe (to highlight the Allied and Central powers) and a time line of major events from 1914 to 1919 (see figure 10). The third panel included a few of 


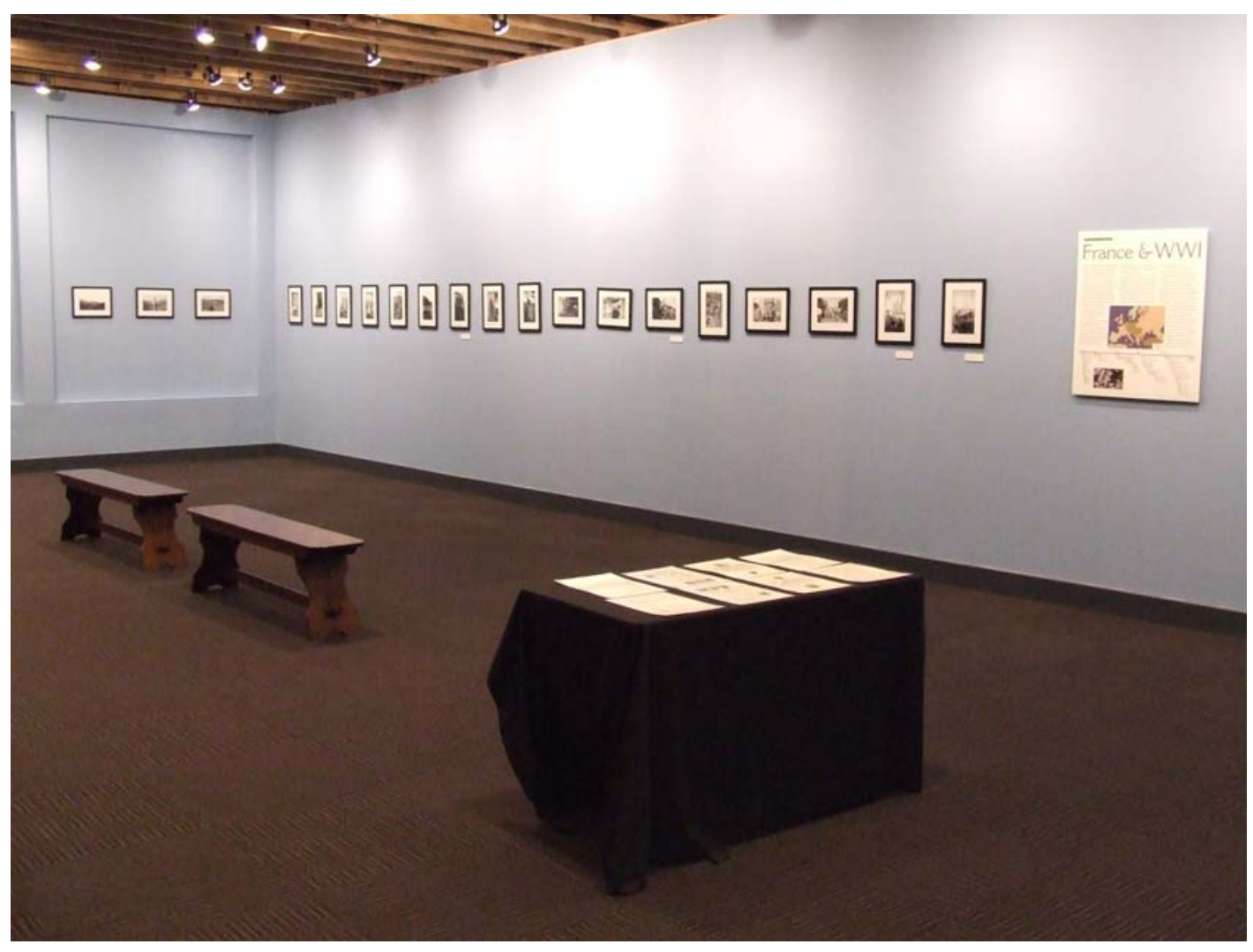

Figure 8. A view of the Jeunet exhibit. The placement of the historical overview panel helped to differentiate photographs taken at the western and eastern fronts. The wall panels helped to pace the visitor by providing pauses between the exhibit's thematic layout.

SOURCE: Photograph by the author. 
Jeunet's writings from his diary during World War I and from a letter he wrote his daughter, Cécile, during World War II on the occasion of her twentieth birthday (see figure 11).

To supplement the information presented on the wall panels, and provide further learning possibilities, several laminated information sheets were placed a small table in the gallery (see figures 2 and 8 ). One sheet featured information about the Kodak folding camera similar to the one Jeunet and other World War I soldiers used. The French had strict rules about photography during the war, since they were concerned about spying, but for some reason unknown to the Spaldings, Jeunet was able to take pictures fairly openly—even occasionally including French officers in his photographs. ${ }^{9}$ The pocketfolding camera he used was the first of its kind to use roll film and was immensely popular during its time. I felt that in order to help understand and appreciate how the photographs were made, and to better understand the nature of popular commercial photography during the early part of the $20^{\text {th }}$ century, information about the camera and film was essential.

Another handout contained recommended listings of books, films, and websites about World War I. I also created a sheet on the history of pacifism in the United States using information from the PBS website related to the series they produced on World War I called “The Good War.” I produced two other information sheets, one comprised of additional writings of Jeunet from World War I and World War II, and the other based on an article I wrote for the museum's newsletter titled, “Ten Ways in Which World War I Still Affects Us Today,” which discussed technical innovations and social and 
geopolitical consequences of World War I that still have resonance today (see handouts in Appendix A).

All of the subjects covered in the handouts were implied in the photographs themselves or mentioned briefly in the text panels. The laminated gallery sheets provided an easy and affordable means of providing more information and explanation. Yet to better understand the conditions and situations shown in Jeunet's photographs, and to help the viewer place Jeunet's experiences in a larger context, I felt that more information was necessary—especially due to the lack of specific information regarding many of the images.

If an additional text panel could have been added, I would have discussed pacifism in the context of World War I and perhaps the large-scale rebellions and mutinies of the French and German soldiers in response to the horrific conditions, scope of death and destruction, and perceived ineptitude or disregard for human life of their military commanders.

Another way I could have emphasized Jeunet's views and helped to interpret the exhibit would have been to include a text panel about war poetry, although I might have risked moving slightly off topic. There is a large body of poetry written by British soldiers during World War I that is so powerful, and paints such a strong message of the ravages of war that few can read it and not have an immediate and visceral reaction. Like the well-known poem titled "In Flanders Fields" by John McCrae

In Flanders fields the poppies blow

Between the crosses, row on row, 


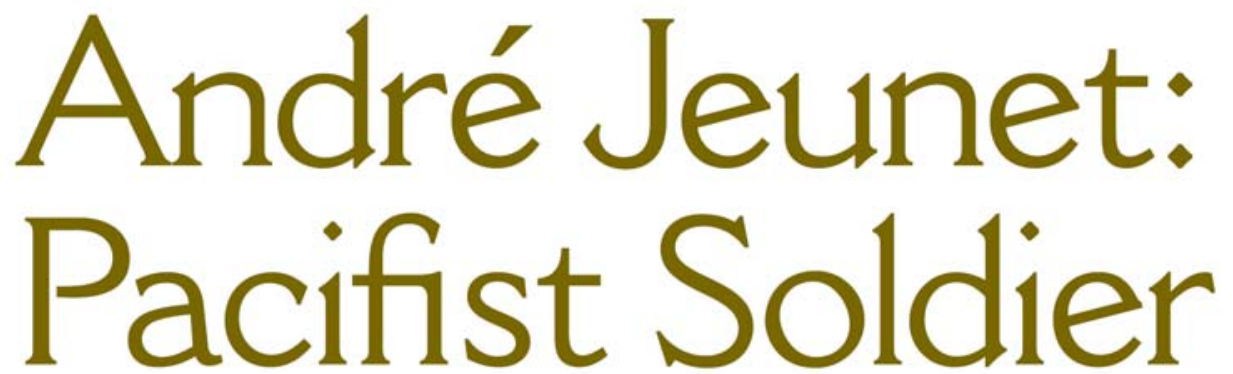

André Jeunet was born September 20, 1896 in Bourg-la-Reine, France, a suburb south of Paris. He was an idealist, a philosopher, a dreamer with a passionate love for the lively arts - his admiration

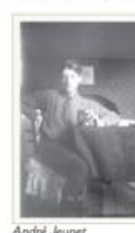

for Beethoven and

Goethe was unlimited.

As a pacifist soldier

during la Grande Guerre,

he, with but a few

exceptions, turned the

lens of his Vest Pocket

Kodak away from the

violence and horrors of battle.

With the sure instincts of the artist, he focused instead on the events of the every-day military life, scenes of troop movements and leisure activities, the countryside, the villages and the people he encountered. There is no record of any censorship by his commanders.

Jeunet's unique images of the Great War present a carefully composed look at scenes seldom portrayed in World War I retrospectives. Those in this exhibit represent but a fraction of his 205 negatives now held in the Special Collections of the Photographic Archives at the University of Louisville.

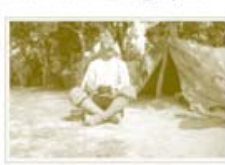

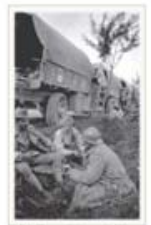

In March, 1915, at age 18 , Jeunet was inducted into the French army. He served on the French Western Front and on the Eastern Front in the Balkans. Jeunet knew the agony of warfare in the front line trenches

but, other than contracting malaria during his eastern stint, he suffered no injuries and maintained good health throughout the four years.

He steadfastly refused promotions, retaining the rank of private. Whenever possible, he sought to isolate himself from the stress of army life, finding solace in observing the rural sites and filling his diary with reflections on life.

On April 4, 1919, in Rasczabanya he was "showered and deloused for the last time,"

declared répatriable" (and) "carried no more trace of

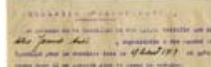
1

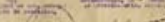
4 xints vermin." He was discharged April 26, 1919.

Following his discharge, Jeunet returned to Paris and became a student of art and architecture. In 1921, he married Aimée Révil-Signorat, and their daughter, Cécile, was born in 1924.
In October 1939, a practicing architect, a veteran of "1914" with a wife and daughter, he was again drafted into the French army. After France's defeat he returned to his family in Paris, undergoing the hardships of four years of German occupation.

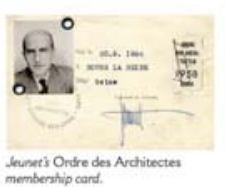

In 1945, Jeunet's daughter Cécile met native Louisvillian, Richard Spalding, during his service in France with the U.S. Air Force. Spalding returned to France in 1948 to study music and they were married in Paris that November. In 1949, the Spaldings settled in Louisville, Kentucky.

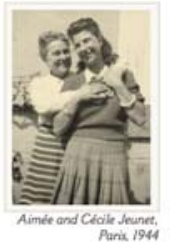

Following a summer visit to the USA in 1952, André Jeunet discovered that l'Amérique was the "country of my dreams." He and Mme. Jeunet immigrated to the United States in 1958. He worked for several architectural firms in Louisville from 1960 to 1970.

Far removed from the war-torn turmoil of his youth, he enjoyed his later years in gentle comfort, surrounded by his family until his death on September 3 , 1979.

\section{Figure 9. Jeunet biography and introduction panel}


In the mid-1860s France was considered the most powerful state in Europe. In 1859 it had twice defeated the armies of the Austro-Hungarian Empire. Yet only seven years later, in July of 1870 , Prussia, led by chief minister Otto von Bismark, would provoke the French into declaring war. The French were quickly outmaneuvered and in a humiliating defeat Paris found itself under siege. By May 1871 with the signing of the Treaty of Frankfurt, France had surrendered the provinces of Alsace and Lorraine to a newly unified German Empire that would quickly change the balance of power in Europe.

These conflicts aggravated long-standing suspicions between France and Germany and led to a series of political and military alliances that would fuel tensions throughout Europe through the end of the $19^{\text {th }}$ and into the early $20^{\text {th }}$ century.
Competition for colonial, economic, and military domination also encouraged the potential for conflict.

In addition to views of the trenches that stretched across Europe, many of the pictures in this exhibit include images of the villagers and landscapes of the Balkan States. The rise of nationalistic fervor in the region, political instability, and the desire for independence from the AustroHungarian Empire and Ottoman Turkey led the area to be called the "tinderbox" which started World War I.

Archduke Franz Ferdinand, the heir to the throne of the AustroHungarian Empire, and his wife visited Sarajevo in June 1914, where they were killed by Serbian assassins opposed to Austrian expansion in the Balkans. The assassinations resulted in Austria's declaration of war on Serbia and triggered a series of alliances that drew much of Europe into the war within a few weeks. The Kingdom of Serbia called on Russia for support, while the AustroHungarians turned to Germany. Planning that France would hold its alliance with Russia, the Germans attacked France through Belgium, an act which drew Great Britain to the Allied side. Most of Europe and Ottoman Turkey would be drawn into the war in the succeeding months. The United States would end up joining the Allies, but not until 1917.

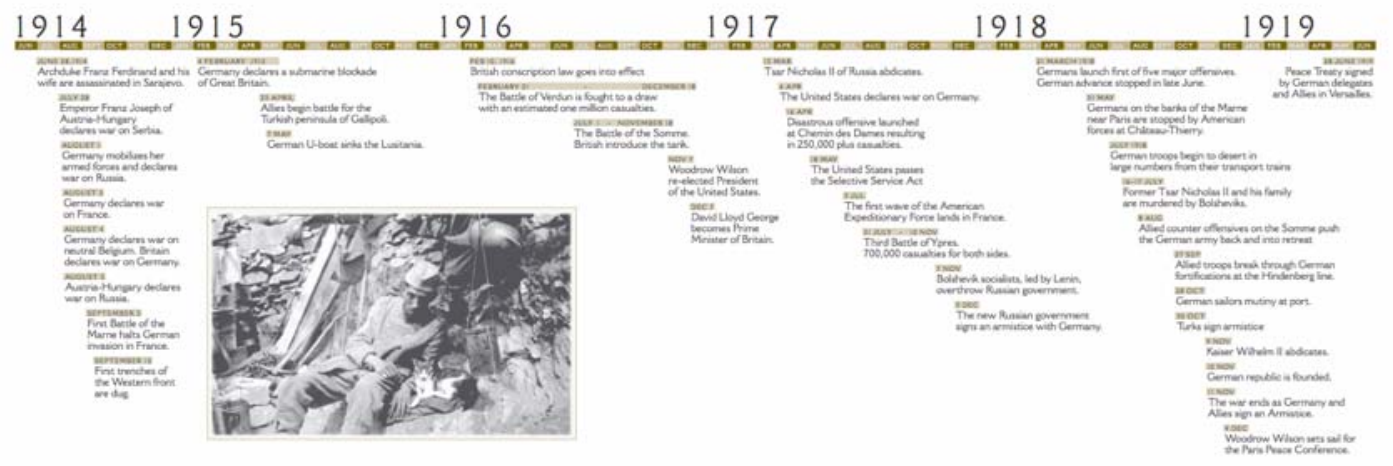

\section{Figure 10. Historical Overview Panel.}




\section{EXCERPTS FROM ANDRE JEUNET'S DIARIES AND CORRESPONDENCE}
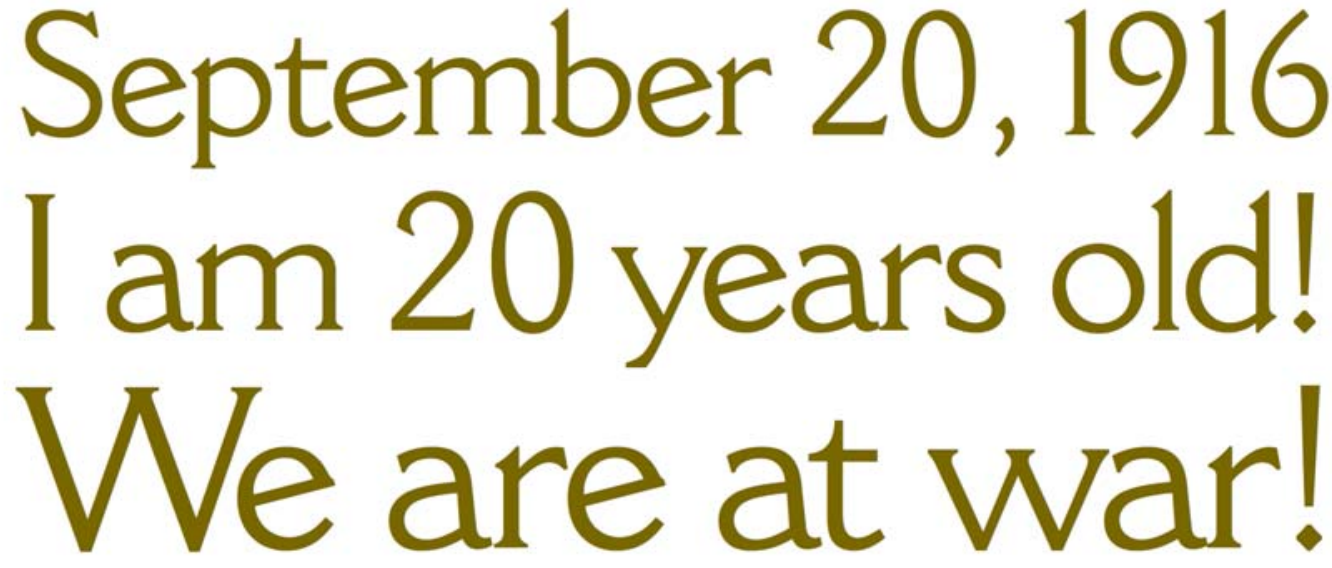

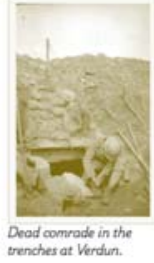

Andre Jeunet recopied hia World War 1 diary entery form September 20, 1916 ostendum for tia deustriter Ckeile on the occarion of her $20^{\text {" birthides. }}$ September 16,1944 .

September 20, 1916. I am 20 years old! We are at war! The 'Great

War' as future historians will say and before its crown will be toppled by the next 'last war'.

We are approaching the end of the famous battle of the Somme, where I risked my life, while I was playing my sad role of infantry man at Chaulnes, a pitiful town, reduced to a few piles of rubble, surrounded by dead trees, branchless as frightful skeleton-like masts of ships, sunken and stuck in this sea of mud, which, in the nearby craters, opened by thousands of shell bursts, forms an unmoving swell.

I am 20 years old! And one cannot perceive the end of the massacre which has already lasted two years.

I am 20 years old and have only before my eyes the horrible spectacle of death. No more leaves, no more flowers, no more animals, even no more grass on the soil...this hilly and muddy ocean engulfs everything - even our souls, without light, and without joy.

September 16, 1916! I am 20 years old, but my body is covered with vermin and my spirit is eaten by doubts.

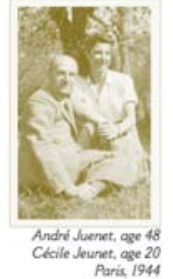

Sixteenth of September 1944 ! Cécile is twenty years old! No more mud, nor lice, but the joyful spring-like parade of bright young friends, gifts, finery, talent, dresses... all illusion!

...For, once again we are at war - entire cities crumble and rain fire on the throngs of innocent mothers and children. My heart is weary to have to write here this bitter preface to a text, older than my daughter by a quarter of a century!"

Paris, September 1944

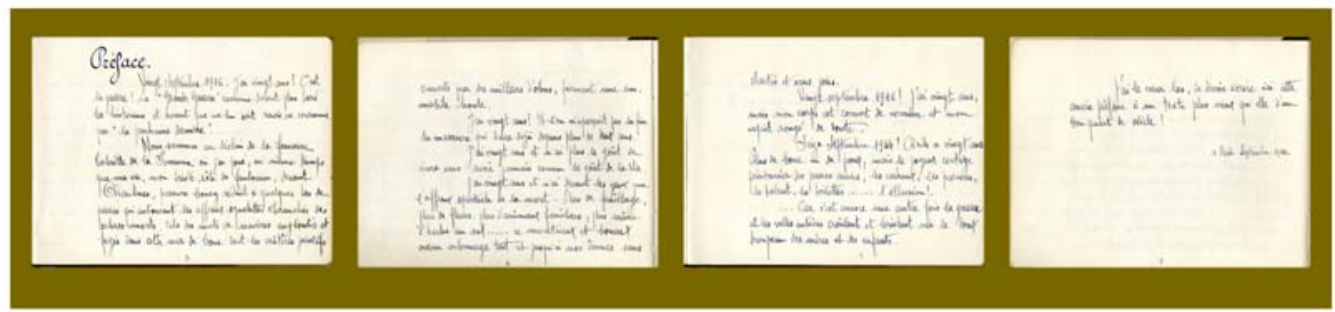

Figure 11. Panel containing excerpts from Jeunet's diaries and letters. 
That mark our place; and in the sky

The larks, still bravely singing, fly

Scarce heard amid the guns below.

We are the Dead. Short days ago

We lived, felt dawn, saw sunset glow,

Loved and were loved, and now we lie

In Flanders fields

Take up our quarrel with the foe:

To you from falling hands we throw

The torch; be yours to hold it high.

If ye break faith with us who die

We shall not sleep, though poppies grow

In Flanders fields. ${ }^{10}$

We were lucky to have Jeunet's writings in the exhibit text to emphasize his views and reaction to the war and to help to humanize and place his images in a more approachable and immediate context. Other photographic exhibits, especially those depicting either a historical period or personality, would benefit from a similar technique. 


\section{CHAPTER III}

\section{INCORPORATING EDUCATIONAL THEORY}

\section{Educational Themes of Jeunet Exhibit}

Jeunet was no different than many other soldiers who documented their experiences in a personal and vivid manner. Some limited their accounts to family and government or museum archival records, while others used their experiences to publish works of non-

fictional or fiction. ${ }^{11}$ Jeunet's views of the war were emphasized through the information on the wall panels and in the laminated information sheets that included more of his personal views through additional transcriptions of his letters. Richard and Cecile Spalding had an excellent feel for the letters and journal entries that would give visitors a sense of Jeunet's moral convictions and artistic sensibilities. I felt that his letters and other writings provided a direct window into his personal experiences and placed them in a historical perspective. I also saw his writings as another way to help create an emotional connection with the viewers. Jeunet's writings were filled with wonderfully descriptive language, and his use of exclamatory sentences shows how emphatically he felt about his experiences and personal philosophies.

Exhibits have traditionally been created by gathering artifacts and presenting them to the public along with a scholarly interpretation of their cultural and historic significance. Museum educators have had the task of developing programs associated with the exhibit such as lectures, gallery talks, and docent-led tours. Between 20 and 25 
years ago, educators working alongside curators and designers in the planning and design of exhibits.

Today, educators in many museums are an integral part in the design and creation of exhibitions, and a growing body of scientific and academic research about learning theory and educational methods is influencing exhibit design and interpretation strategies and methods. Research on museum education is still in its infancy as a recognized research field. In addition to traditional sources of input from current and former classroom teachers, scholars, or content specialists, museum education is now benefiting by using the latest educational theories, as well as behavioral, cognitive, and neurological studies, and supported by the results of visitor studies and evaluative research. ${ }^{12}$

\section{Using Educational Theory to Expand Learning Opportunities}

Although I did not base the Jeunet exhibit solely on specific educational theories and outcomes, I did incorporate several of the more popular educational concepts currently used in designing exhibits. There were several ideas I actively considered while producing the exhibit. I will briefly outline a few of the more popular schools of thought currently used by museum educators.

One such approach that has influenced both teachers and museum educators is Howard Gardner’s theory of multiple intelligences. Gardner initially outlined seven, eventually expanding to eight, ways that we approach learning. These learning styles include verbal-linguistic, logical-mathematical, spatial, bodily-kinesthetic, musical, interpersonal, intrapersonal, and naturalist. ${ }^{13}$ In essence, all of us approach learning using 
words and language, numbers and patterns, visualization, touch and movement, music and sound, and nature or natural phenomenon. Learning is also influenced by working in either in groups or by ourselves. Gardner’s theory has influenced museum educators who realize that there are various ways in which students and adults relate to exhibits, programs, and activities.

I did not address all of Gardner’s intelligences when conceptualizing and implementing the Jeunet exhibit; however, several elements were strongly represented. Verbal-linguistic learners would have been drawn to the exhibit's written materials in the form of wall panels, photography labels, and handouts provided in the gallery. Spatial learners, aside from the photographs themselves, would have focused on the way I used the physical layout of the gallery including image placement, traffic flow, height of and margins between each photograph, and the map and images integrated into the wall panels. Intrapersonal learners would have been drawn to using the handouts, since they were designed for individual use to glean additional information. The handouts would have also appealed to bodily-kinesthetic learners—providing a medium that they could hold and physically manipulate.

Linda Darling-Hammond, a professor at Stanford University, along with coauthors Jim Rosso, Kim Austin, Suzanne Orcutt, and Daisy Martin, outline an alternative to Gardner of how learning takes place by describing seven developmental domains, or "pathways," including the physical, the social-interactive, the emotional, the cognitive, the linguistic, the psychological, and the moral-ethical. ${ }^{14}$

The physical pathway includes spatial elements and is influenced by environmental concerns, including the floor plan, colors of the gallery, lighting, and other elements of 
the physical space. It also relates to a visitor's motor skills and physical dexterity in manipulating hands-on activities, multimedia displays, and other types of exhibit enhancements. Issues of space, layout, and the physical environment not only affect learning but museums have a civic and ethical responsibility in making exhibits and displays accessible to visitors with physical and learning challenges. ${ }^{15}$

The social-interactive pathway has led museums to move away from creating exhibits geared toward individuals and to understand that learning is strongly influenced by opportunities for social interaction and interpersonal dynamics. Many museums have used this as an opportunity to design exhibits that engage visitors with interactives, encourage learning as family units, or create opportunities for visitors to learn in groups. Encouraging interpersonal learning could be as simple as a docent-led tour, gallery carts, or other situations where visitors are required to interact with schoolmates, family members, other visitors, or museum staff. ${ }^{16}$

The emotional pathway provides museums with a powerful opportunity to connect with visitors. I know this from personal experience. My visit to the U.S. Memorial Holocaust Museum was emotionally moving, and at times nearly overwhelming. When I came upon the display with the pile of children's shoes, it was all that I could do not to openly tear up. Exhibits can generate a wide range of emotional responses-fear, anger, joy, sentimentality are just a few.

With museums adapting their missions as agents of social change and striving for social relevance, exhibitions can be specifically designed to cause an emotional response. Sometimes an exhibit's content can be so controversial that emotional responses are almost automatic. The exhibit of the Enola Gay at the Smithsonian Institution in the early 
1990s caused a firestorm of emotional responses when the curators tried to address the question of whether the United States should have dropped the atomic bomb on a target that included so many civilians. ${ }^{17}$ Topics such as reproductive rights, civil rights, certain types of scientific research, environmental issues such as global warming, and evolution can cause, and have caused, museums much consternation.

One of the best examples of emotional or affective interpretation is the work of art historian James Elkins, who has studied why certain works of art elicit strong emotions, including crying.

Initially I thought crying would come in as many varieties as there are people. The scattered stories started falling into patterns. Roughly half the cases converge on two kinds of experiences that are very close to each other and yet completely opposed. In one, people cry because pictures seem unbearably full, complex, daunting, or somehow too close to be properly seen. In the other, they cry because pictures seem unbearably empty, dark, painfully vast, cold and somehow too far away to be understood. ${ }^{18}$

Although tears may be an extreme example, I wanted the Jeunet exhibit to generate an emotional response in visitors. Since the photographs focused on one person and his travails during wartime instead of scenes of various or anonymous soldiers, the works I selected helped viewers see Jeunet as a real person and hopefully facilitated an empathetic response or connection. I emphasized Jeunet's humanity by tying his photographs to his biography and selection of personal writings provided in the gallery. All of these elements gave some insight into the person and perhaps invited viewers to find ways to connect with the photographs based on their own experience with conflict. In retrospect, an additional text panel or handout discussing the human cost of World War I by listing casualty statistics would have also helped generate an emotional response and tie into another of Gardner's learning types-the logical- mathematical. The 
number of dead, wounded, and missing were staggering compared to any other armed conflict in history up to that time.

\section{Practical Applications for Photographic Exhibits}

The cognitive pathway has certainly had a major impact on museum educators interested in learning more about how learning takes place in museums, and what types of learning and retention occurs during a single visit, and how learning changes over a series of visits during a designated timeframe. Researchers John Falk and Lynn Dierking have spent the last 20 years trying to answer these questions. In their books The Museum Experience and Learning from Museums, Falk and Dierking attempted to prove that learning takes place in museum, even if it is a process they admit needs additional research. $^{19}$

The question of exactly what types of learning take place in museums, there is an awareness of how museums play a role as sources of reliable information in what Falk and Dierking categorize as having transitioned into a "Learning Society." ${ }^{20}$ Museums are rising to the occasion by attempting to offer both structured and what Falk and Dierking term “free-choice” learning.

Free-choice learning gives visitors the option of participating, compared to a classroom program in which each participant follows a prescribed lesson plan. Freechoice learning might come in the form of computer interactives, touch items, hands-on activities, or even interactions at demonstration carts. Free-choice learning opportunities 
include the exhibit itself and handouts provided in the gallery. In other words, visitors have the ability to select their own routes through the exhibit and to choose which panels and labels to read and which (if any) handouts to peruse for supplemental information.

Structured learning depends more on the delivery of specific information instead of personally directed activities. In museums it takes the form of docent-led tours, classroom programs, and other didactic activities. The only structured learning offered in conjunction with the Jeunet exhibit was a lecture by Katherine Burger Johnson on medical advancements during, and as a result of World War I. Johnson, an archivist and historian specializing in the history of nursing during World War I, is on the staff of the University of Louisville Archives and Medical Library. Her lecture was informal and very well received by a small and enthusiastic audience.

Darling-Hammond et al., in addition to describing the cognitive pathway, include three other developmental stages or pathways: linguistic, psychological, and moralethical. The linguistic refers to literacy and how one communicates; the psychological deals with a sense of self; and the moral-ethical applies not only to issues of right and wrong, but how we judge ourselves and others in terms of the common good, justice, social welfare, and citizenship. ${ }^{21}$

All of these elements were woven into the Jeunet exhibit. Although simple and straightforward on the surface, the exhibit contained a complex and rich assortment of underlying themes providing visitors ample opportunities to consider the images in terms of history, philosophy, psychology, and politics. Education and learning theory provide tools for curators to empower their audiences to mine riches from both complex and simple photographic exhibits. 
The exhibit's wall panels, photo labels, and handouts are examples of the linguistic pathway, in that they use language to convey information and create a dialogue with the visitor. But the photographs themselves offer a type of visual language-especially if the visitor is able to view the images in terms of the information they contain which does not require a written language to convey.

Philip Yenawine, cofounder of the nonprofit research organization Visual Understanding in Education, has written extensively on how to enhance and find new meaning in art. He conducts workshops and seminars to help educators understand and teach what he terms "visual thinking strategies." These strategies are designed to impart the necessary skills to decode and find meaning in an image, much like the skills necessary to decode and understand written language. ${ }^{22}$ The lack of text in the Jeunet exhibit placed more emphasis on the photographs and gave the visitor more discretion to interpret them without the curator's influence. Still, there was enough text to give the viewer a basic understanding of the photographer, the photographs, and the context so that the images could convey their own messages without further elaboration.

The psychological aspect of the Jeunet exhibit dealt more with the photographer than the viewer. In many exhibits this is easily addressed by adding wall panels or interactives that encourage exploration of the exhibit's themes. In hindsight, I would have added an interactive element in the form of a corkboard or other simple mechanism where visitors could have posted their responses to the following questions:

- How do you think you would have handled being a soldier in World War I? 
- In what ways would you have taken pictures similar to or different from Jeunet's? If different, what things would you have captured on film that are not in Jeunet's pictures?

- What do you think these pictures say about the photographer?

- How is it is possible to be a soldier and also opposed to war?

- How would you describe the photographs in this exhibit?

This would have provided a wonderful record of how visitors perceived the exhibit and also created an ongoing dialogue among visitors. It would also have helped to bring a sense of self to visitors by providing an opportunity for them to project themselves into the images and to relate their own feelings as well as to empathize with others. This approach ties in with what I call the "So What?” approach to designing exhibits. The "So What?” is trying to ensure that whatever is presented has relevance and meaning to the visitor. One way I tried to provoke an emotional response, or provide a personal connection to the material on display was by creating supplemental resources in the form of gallery handouts (see appendix A).

I believe that any display of images relating to war ought to address the moralethical dimension, the final developmental pathway. Hopefully, addressing the issue of pacifism and Jeunet's fervent opposition to war caused visitors to reflect on their own feelings about the moral and ethical dimensions of war and conflict. The handout on the history of pacifism let visitors know that this same issue has been associated with every American military conflict since the Revolutionary War. ${ }^{23}$

Two additional educational theories that continue to influence museums are constructivism and inquiry-based learning. Visitor come to museums with a basic 
foundation of knowledge, and given the right opportunities, will "construct" or build onto their existing knowledge and experiences in order to bring meaning to their experiences. ${ }^{24}$ Some visitors bring little prior knowledge of the topics or artifacts presented in museums while others bring a wealth of knowledge or experience. Museum educators must provide the proper balance of informational and experiential opportunities so that visitors can better appreciate, understand, and relate to exhibits. In many ways, constructivism transcends the immediate experience and provides a platform for lifelong learning. Some visitors to the Jeunet exhibit brought a substantial foundation of information regarding World War I, photography, or in some cases both. Others brought only scant knowledge of either subject. By viewing learning as a series of building blocks with each block representing pieces of information and experiences, museum educators can create rich multisensory exhibits to help visitors learn basic information, build on what they already know, and make direct connections to their lives. I created the handout “10 Ways in Which World War One Still Affects Us Today,” to help visitors see connections to the present and understand how a war that took place nearly 100 years ago can have lasting implications.

Photography exhibits, like artifact exhibits, can include video, computer interactives and other multimedia presentations to help visitors make sense of the images. The Jeunet exhibit would have benefited greatly from having a small computer kiosk in the gallery with film clips from World War I and audio clips of comments from Jeunet's family. This would have provided visitors with a stronger connection to the time and allowed another way to humanize Jeunet with a series of recollections and stories about the photographs and the photographer. This attempt using constructivism in museum settings is part of the 
experience defined by Falk and Dierking when they talk about making connections and free-choice learning.

Learning experiences successfully take into account the factor of prior knowledge, interests, and beliefs when they provide "hooks," or entry points, that enable learners to relate their previous experiences to this new one, be it new information being presented in an exhibition or program or an aesthetic connection being made through a special art gallery performance. Learners what to be able to "see themselves" within an exhibition, program, even a website. Either consciously or unconsciously, they are seeking ways to connect this particular exhibition, program, or website to who they are and what they need and /or are curious about. In order for this to occur, at some level learners have to understand why this particular experience is relevant to them and, if they attend to it or participate in it, how the experience and information contained within it will enhance their life. ${ }^{25}$

The theory of inquiry-based learning is another methodology that has influenced

how museums design environments and exhibits to encourage discovery and engage

visitors. Inquiry-based learning is much more than getting learners to ask questions, it is

proving the stimulus and opportunities to invite and encourage further investigation.

A good medium of communication permits the participant to seek the level of engagement and understanding appropriate for the individual. It is often said that a good exhibition, performance, film, etc., can be understood at many different levels and from many different perspectives. By this it is meant that the learner can become engaged via many entry points [my emphasis] and can be challenged at a variety of different skill levels. Thus engagement, a flow experience, can result because there is sufficient depth to permit appropriate levels of challenge for a wide range of users. In free-choice learning situations, learners can select the challenge they wish, rather than have it imposed upon them. ${ }^{26}$

Noted author and museum interpretive specialist Graham Black asks the question many museums struggle with today regarding how to ensure learning actually occurs.

If we accept the potential for museums as leaning institutions, what do the relevant learning theories mean in terms of the physical way that collections are presented, and the ways in which we should support this presentation to 
meet the differing needs of users - effectively in terms of how we develop 'learning environments'? ${ }^{27}$

In his book The Engaging Museum: Developing Museums for Visitor Involvement, Black answers it when he writes

Learning theories are not enough on their own to enable us to develop exhibitions that 'work' with visitors. Alongside them must sit an understanding of the experiences visitors seek. Although relating to museum programmes rather than exhibitions, it is useful, for example, to look in this context at the responses of adult programme participants to this question... More than 70 per cent wanted hands-on activities while 80 per cent felt it was important to have access to unique people, place and objects. 85 per cent wanted time for questions and discussion. More than 94 per cent wanted new or challenging content. Yet interaction with the instructor or interaction with other program participants - or interaction with both - was regularly cited as the one thing program participants remembered most. ${ }^{28}$

Black seems to be saying that even with computer interactive technologies and the ability to provide a dynamic kinesthetic experience, museums rely on the interaction between visitors and staff, docents, artists, or other authorities to provide memorable events. In addition to the one lecture we provided in conjunction with the Jeunet exhibit, we could have offered gallery talks or special tours if we had had access to photographic experts or historians, and additional funding. Audiovisual displays would have made a dramatic impact on the learning potential of the exhibit. Original film footage of World War I with scenes of soldiers pouring over the top of trenches, the first machines guns, tanks, and airplanes used in battle would have helped placed the photographs in their historical context. Audio recordings of Jeunet's letters and journal writings would have strengthened the affective qualities of the exhibit and made the exhibit more accessible to visitors with visual impairments. 
With access to pedestals or small cases with covers, I could have exhibited some of Jeunet's original letters or borrowed several World War I period objects to display. Photography exhibits are often effective on their own, yet they gain important educational dimensions with the addition of artifacts, and in some cases, reproductions. (Although I am often reluctant to use reproductions in museum settings, they can provide important educational benefits in certain situation when properly identified).

The benefits of understanding and using educational theory cannot make a badly conceived exhibit coherent, but it can transform the way museums and art galleries design their displays. By understanding how people learn, curators working together with educators, can design exhibits that resonate more effectively with visitors. The goal when applying educational theory in museums and art galleries is to ensure that the exhibit successfully conveys the intended messages, engages the viewer, and encourages visitors to learn more about or discover other aspects of the history, artifacts, art, themes, or personalities presented in an exhibit. Most importantly, the exhibit should leave a lasting memory or impression that visitors can draw on throughout their lives.

My recollections of childhood visits to the Smithsonian Institution and Chicago's Field Museum and Museum of Science and Industry remain vivid along with later visits to the Metropolitan Museum of Art, the U.S. Memorial Holocaust Museum, and the National Gallery of Art, which continue to serve as points of reference. Falk and Dierking document such museum experiences in Learning from Museums when they use as an example an exhibit titled Think Tank at the National Zoo that explored what is known about how animals think and learn. 
Not only was their evidence for learning from the exhibit, but also over half the visitors in the call-back group self-reported that the exhibition had influenced their attitudes toward animals, and half indicated that it influenced their behavior with respect to animals. For example, some individuals said that the zoo experience prompted them to watch relevant television shows, others said they were inspired to read books on the subject, and still others the exhibition caused them to engage in conversations on the topic of animal learning with friends and/or family. All in all, the data provided evidence that a slight majority of visitors experiencing the Think Tank exhibition had improved understanding, changed attitudes, and even changed behaviors relative to animals and the ways they think. ${ }^{29}$

Photography is such a powerful medium. In turn, the photographic exhibit has never reached it potential since in most cases its presentation is focusing primarily on the aesthetic. Photography still contains many ifs: if you happen to be interested in the subject, if you're familiar with the context, if you happen to have enough experience in how to look at the images, and if you know what to look for, you will probably get something out of the experience. I take some solace in the fact that what and how people learn in museums is yet to be definitively defined. George Heine in his book Learning in the Museum discusses the importance of providing a context for visitors. Heine has been able, like Falk and Dierking and others, to show that some type of learning or "meaning” occurs, but the specifics are perhaps less important than the imaginative or role-playing aspect that exhibits can encourage.

Learning can only occur when visitors can connect to what they already know, can make an association between what they bring to the exhibition and what is presented. Thus, visitors respond favorably to art museum labels that personalize the artist and the works of art, children engage in "fantasy play" at science centers, and families reconstruct their own histories and personal connections with the events illustrated at historic sites. ${ }^{30}$ 
I feel that the Jeunet exhibit was successful aesthetically, but I wish it could have been transformative; in other words, I would like to have created an exhibit that changed the way visitors thought about war, spurred their interest in pacifism, or encouraged them to learn more about a war where approximately six to seven million French soldiers were casualties for no tangible gains or obvious benefit to world peace, stability, or justice.

Curators need to see museums and art galleries as not only opportunities to inform but also vehicles of social change. The incorporation of education theory more effectively provides both immediate and long-term learning opportunities when exhibits challenge viewers, generate discussion, cause visitors to question what they may already know, and create the desire to pursue additional learning about a particular topic or subject. 


\section{CHAPTER IV \\ USING TECHNOLOGY TO EXTEND THE \\ EDUCATIONAL POTENTIAL OF AN EXHIBITION}

\section{$\underline{\text { Web-Based Technologies }}$}

Photography is an important part of the museum exhibition repertoire, and with today’s technology, photographic exhibits can continue to inspire and educate. The digital revolution has provided museums with a range of tools to archive, document, and interpret exhibits — in turn providing dynamic alternatives to the days when exhibits only lived on through the publication of printed catalogues. Today a museum's website and other forms of electronic and digital media provide new and constantly evolving ways to extend the reach and impact of its collections. Where museum's websites used to be primarily geared toward providing information aimed at attracting potential visitors, they now also serve as a delivery method for both pre- and post-visit materials.

Although many museums have been creative in their use of websites as an advance organizer for a visit, there is no reason why websites could not also serve post visit purposes, for example, by providing opportunities for visitors to get more in-depth information, further explore a topic of interest, or engage in some related activity. ${ }^{31}$

Website traditionally served as an informational delivery network; however, they also have the ability to allow for numerous interactive possibilities for a museum or art 
gallery's exhibits. They also can provide virtual or online exhibits. A quick search on Google turned up numerous individual museums, as well as 24hourmuseum.org.uk, a website which serves as a centralized consortium for British museums offering a variety of online exhibits. In terms of extending the life of an exhibit beyond the time it is physically located within a museum and on public view, the Internet is a powerful venue.

With enough time and resources, the Jeunet exhibit could still be available in such a format. In fact, many of the additional aspects I mentioned in chapter 3, including audio and video, could easily have been combined with the images in an online exhibit. In addition to including a selection of images from the exhibit, I would have included an audio podcast with members of Jeunet's family, an interview with a local historian who specializes in the history of Europe during the early $20^{\text {th }}$ century, and an English or humanities professor able to discuss poetry written by soldiers in the First World War. In creating an online exhibit, I would have enhanced the material by supplementing the images with new commentary as I continued to analyze the photographs and gather new information and insights.

It would have also been worthwhile to develop a curriculum to use in conjunction with the photographs. In Kentucky, the sixth-grade social studies curriculum emphasizes geography; seventh-grade, world history; and eleventh-grade, U.S. history from Reconstruction to the present. The Kentucky core content for assessment provides ample gist for integrating France and World War I into the programs of study for all three grade levels. The sixth grade curriculum could have students examine how borders of European countries changed before and after the war. In some cases boundaries changed, and in others (especially the Middle East) entirely new countries were created out of preexisting 
territories. The seventh-graders could have examined how Europe changed socially, politically, and geographically as a result of the war. Eight-graders could have studied World War I and World War II and could have used many of the images from the Jeunet exhibit to compare images between the two conflicts and assess how technology and advances in military weaponry would change the nature of war and its effect on those countries involved.

\section{$\underline{\text { Audio Tours and Podcasts }}$}

Technology in creating and preserving exhibits offers a lesson in contrasts. On the one hand, it provides for the transmission and storage of something well beyond its physical terms; on the other hand, technology can be by its very nature ephemeral. What is popular one day is quickly outdated and outdistanced by other technologies and preferences. Several articles in the July/August 2006 issue of Dimensions, a bimonthly publication of the Association of Science-Technology Centers, touts blogs, podcasts and wikis as "social technology" tools for museums. ${ }^{32}$ While many museums are using these platforms, the digital landscape is changing very rapidly and many organizations may not have the resources to keep pace with its evolution.

Podcasts allow curators to bring in multiple perspectives, provide insights into a collection (or photographic exhibit in my specific case) that cannot be addressed in an exhibit due to space or text limitations, and introduce sounds that enhance the experience of simply viewing an exhibit. I could have used music that was popular in France during the war as an underpinning to not only deliver information but provide a way to tie the 
listener to the time and create an environmental experience. If done correctly, podcasts can be tailored to specific audiences, ages, and interests. With audio, it is easier to create a narrative in the tradition of storytelling and use either one or several voices to add contrast and variety.

In the article "Sounds Good to Me: Using Digital Audio in the Social Studies Classroom,” the authors outline a relevant combination of lesson plans and podcasts to enhance learning in the following four ways: ${ }^{33}$

1. To supplement curricular goals

2. To update students on current events

3. To inform students about the political process

4. To take students where they otherwise couldn't go

These same authors use World War I to show how this technology can enhance classroom teaching and concomitantly show an education correlation to museums and galleries.

In the study of World War I, textbooks and other print sources often fail to capture the human element of life during this great conflict. The website "First World War.Com" has an entire section devoted to songs, speeches and descriptions of that era. Among these sound files, teachers and students can hear several versions of George Cohan's “Over There,” a popular song in the United States after the U.S. entry into the war. Students could listen to this song while studying life on the homefront during the war and use the lyrics to examine motivations for young people to go off and fight in Europe. ${ }^{34}$

\section{Passive and Interactive Media}

In addition to employing the standard website, I could have set up a blog (web log) site and linked it directly to an online version of the exhibit. The advantage of a blog is that it is easier to maintain, even for those with even a minimum of technical ability; can 
handle text, graphics, audio, and video; is available for little or no cost; and is interactive. Blogs have the ability to solicit comments or reactions from visitors to the site, which creates a treaded discussion between the site and its visitors. A blog associated with an exhibit would allow curators and educations to provide information and encourage discussion or reactions to an exhibit's topics and themes. This technology has already proven its mettle in classrooms. In the April 2006 issue of Social Education, a magazine for social studies teachers, C. Frederick Risinger wrote an endorsement for the qualities of blogging in his article, "Using Blogs in the Classroom: A New Approach to Teaching Social Studies with the Internet.”

After years of feeling that I was fairly knowledgeable about technology computers, software, the internet - recent innovations make me feel like an amateur. I had read about teachers using blogs in the classroom, and I vaguely knew what blogs (short for "web logs") and podcasts were. However, I hadn’t realized how many educators were actively transforming teaching by changing student-to-teacher, student-to-student, and student-toinformation interactions. ${ }^{35}$

Risinger uses the word "collaboration" to show how this technology has become an interactive venue. A blog would have allowed me to create a virtual "guest book" in which those who visited the exhibit could leave their remarks, impressions, and questions. This technology also provides curators and museum educators a possible means to dialogue with their audiences by responding to and providing information through an interactive online discussion/message board. Not only does this technology give an exhibit an indefinite lifespan, it provides the capacity to reach a large and diverse audience.

Online exhibits offer a multitude of ways for exhibits to not only continue past their normal life with the ability to add new information and update the online version. Since 
the Jeunet show closing, I have gathered additional information about the photographs and pieced together new facts about Jeunet's military service and travels from the western front to the "Orient" (a term the French military used to refer to the eastern front in Greece, Serbia and Albania) ${ }^{36}$ (see figure 11). The Internet provides a flexible and ambidextrous platform to allow photographic exhibits to maintain an ongoing presence that is accessible to a much larger audience and not bound by a predetermined time and space. Online exhibits, especially those enhanced with images, audio, video, education resources, and links to other related and substantive websites, fill an important venue for classroom teachers and students as well as lifelong learners of all ages. 


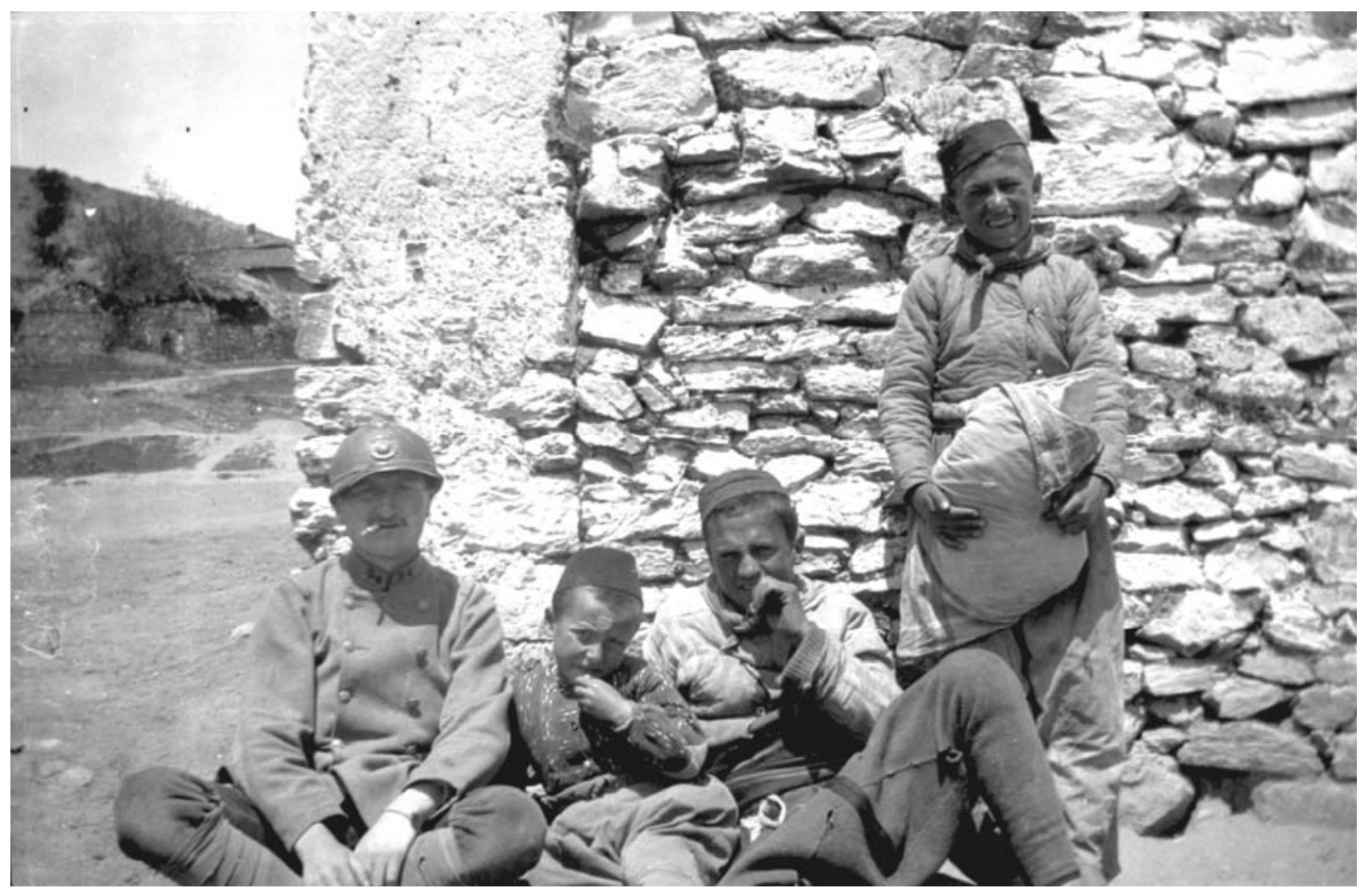

Figure 12. A comrade of Jeunet's with village kids in the Balkans (probably Serbia). The French infantry wore regiment numbers on their jacket collars. If the image is enlarged, the number 34 is clearly visible. The history of the $34^{\mathrm{e}}$ Colonial Regimen, and its deployment to the eastern front during World War I, closely matches details in Jeunet's writings and journal.

SOURCE: André Jeunet Collection, Special Collections Photographic Archives, University of Louisville. 


\section{CHAPTER V}

\section{CONCLUSION: THOUGHTS AND REFLECTIONS}

\section{$\underline{\text { Assessment of Education Objectives }}$}

The question remains, what if any actual leaning takes place in museums? Various models and research show learning in museums occurs, but the specifics regarding experiences leading to gaining skills and building long-term knowledge remain vague. The potential certainly exists; however, in an article that appeared in ASTC Dimensions, the journal of the Association of Science and Technical Centers, author Richard Toon laments that the premise of learning in science centers is "hard to prove." 37 Toon states that most museum professionals may agree that science centers exert a positive influence on how science is understood, but they differ on the current approaches many museums use in their assessment.

Since I did not create an audience evaluation component to accompany the Jeunet exhibit, I cannot address how, or what, visitors learned. An exact science of evaluating museum learning is still in its early stages; however, something as simple as a guest register and comment book would have allowed me to gain some sense of how certain visitors perceived the exhibit and perhaps given me clues to the thematic impact(s) as well. But comments provide only one method to whether any type of learning actually has taken place. The other shortcoming in placing a comment book in an exhibit or gallery is that it can skew your data, since normally only those visitors who are motivated will take the time to leave their information. 
In a more formal assessment, visitors are more directly targeted and solicited, so data reflects a more even representation of all visitors to a particular gallery or exhibit. The standard method used by many institutions involves various stages of gathering data such as surveys, interviews, visitor observation, and focus groups, and analyzing press and media coverage.

I could have left survey forms or comment cards at the entrance and exit to the gallery, but it wouldn’t include responses from those who did not feel either a need or desire to provide their feedback. In many cases, those are precisely the visitors museums need to engage. After all, if learning is an important objective, does it mean those visitors who are not moved to leave a response do not have the same experience as someone who does? The only way to find out is to provide a method of collecting data that is as consistent and even-handed as possible and that presents a variety of assessment mechanisms such as simple "yes” or "no" questions, scaled responses (from 1 to 5 or “poor” to “excellent”), and opened-ended questions.

I would have been interested in gathering basic demographic information such as ages and zip codes to get an idea of who saw the exhibit and where they lived. I would also have asked if visitors liked the exhibit, if they felt it told them something new, or if they had ever considered the idea of pacifist soldiers. I would have liked to know what, if any, effect the exhibit had on visitors. Open-ended questions would have given me the opportunity to ask if the exhibit changed visitor's perceptions of war, provided them new insights into World War I, left them with questions or ideas to consider, or if the photographs moved them personally. Another easy mechanism used in small exhibits is a 
comment board that may ask one or more questions and provides pieces of paper to write a response and post on the board.

As much as museum educators try and affect visitors and work with curators to develop exhibits that engage through transmitting and building knowledge or skills via personal choice, the option of guided learning provides exhibits a real opportunity to use collections as a catalyst for learning. Unfortunately, many teachers lack the skills, insights, or time to understand how a trip to a museum and its online equivalent can provide students with a unique learning and teaching opportunity. Providing lessons plans in the form of pre- and post-visit materials can (when properly used) allow teachers and home schooling parents the interpretive means to use a trip to a museum or gallery as a way to deepen their curriculum and integrate the use of artifacts and primary sources into their learning process.

The pre-visit materials focus on preparation and building the foundational knowledge that provides a richer and more familiar context to the visit. Since learning in museums is often based on making associations with prior knowledge and experience, providing planning materials in advance helps teachers create a basis for more in-depth learning opportunities both in the classroom and the museum as well.

George Hein in his book Learning in the Museum, discusses writings by authors D.P. Ausubel and C.G. Screven, who show that materials they call "advance organizers” help visitors organize the time spent in museums, thus maximizing what they are able to do and see. Orientation maps and guides, overview information, and suggestions of collection highlights assist visitors in planning their time. 
Informing them explicitly in advance what they are going to see, what they might find, or what the intention of the exhibition is, makes visitors more comfortable, more able to engage with the exhibitions and, therefore, better able to learn. ${ }^{38}$

Roos Loomis, in Visitor Evaluation, part of the American Association of State and Local History management series, broaches the subject of what and how people learn in museums when he introduces the term museum literacy.

Finding learning criteria that fit the exhibit setting as well as other kinds of experiences that museums provide will require research into the ways people use museum and the kinds of skills they develop. In time, this research could lead to learning criteria specifically focused on museums. What are the special features of museum environments that promote learning? How do museum differ from other settings in the opportunities they offer for learning and how do visitors adapt to museums in ways that maximize their ability to learn? This last question opens the possibility that museum-visitor learning cannot be understood simply from the perspective of the setting or from what museum designers and other professionals can build into exhibits and programs. Learning also involves the ways in which visitors react to the setting and the kinds of learning strategies they bring with them. Those learning strategies may evolve, over time, and it is possible to enrich visitor experience by directly suggesting ways to study objects and visit exhibits. Museum literacy is a term, growing in use, that describes the visitor's skill at coping with the museum environment. In a narrower sense, museum literacy refers to the visitor's "reading” or interpretation of museum objects. A broader use of the term encompasses the visitor's successful use of all information sources within the museum setting. ${ }^{39}$

So a large part of ascertaining whether the Jeunet exhibit, or any exhibit, provides valid learning opportunities is based on how well a museum or gallery assists its visitors in orienting themselves and provides ideas and suggestions on not only what to see but how to see. In the year following the closing of the exhibit, I had the chance to continue researching the photos and cull more information about their historical context. This information would have helped the viewer and provided a richer context to understand World War I and Jeunet’s experiences. 
In the final analysis, the conceptualization, planning, implementation, and execution of an effective photographic exhibit is based on a series of decisions which in turn cause the curator to establish priorities. Human resources, finances, time, space, conservation considerations, and the photographs themselves all play a role in determining objectives and influencing decisions and priorities.

In the Jeunet exhibit, space influenced the number and placement of images. Financial considerations forced me to carefully consider the number, size, and physical aspects of interpretive devices such as labels, wall panels, and handouts. Conservation considerations influenced the choice of break-resistant glass and matting material in displaying the images. Since the images were printed from digital scans of the negatives, special lighting was not required. Even the gallery itself presented a unique set of challenges and considerations. Some walls were completely flat, others had once had window bays, and one side was composed of brick and mortar.

The exhibit provided me firsthand experience in developing a concept, identifying objects, and conducting the research necessary to effectively convey an exhibit's inherent themes and ideas. Although I did not make direct correlations between the Jeunet exhibit and the situation with the war in Iraq that was raging at the same time, an honest and open discussion of patriotism, pacifism, and how one can be a soldier and yet be morally opposed to war was worthwhile and germane. I also feel that curators owe it to their audiences to consider specific and concrete "take-aways" when planning and organizing exhibits. The exhibit proved to me that establishing a main theme and setting education objectives help to anchor the curatorial process by influencing decisions concerning resources, space, lighting, funding and the more tangible issues that determine the 
eventual look and feel of an exhibit. Whether it is a student show at a university gallery, or a multimillion-dollar exhibit at a flagship museum, educational objectives need to be determined during conceptualization rather than a fortunate by-product once the exhibit is on display.

Understanding how people learn and their learning preferences led to determining educational objectives and help clarify why the exhibit is being created and its "big idea." In addition to the number of artifacts or works of art displayed, curators need to think in terms of thematic goals and objectives. They need to consider what they want their audience to take away from the experience and understand that visitors bring with them an array of information, skills, attitudes, and learning styles. Applying educational and learning theory can help offer a multitude of ways to engage visitors by determining how exhibits can appeal to multiple learning styles and preferences including socially, mentally, aurally, visually, physically, and spiritually. Graham Black comes to a very similar conclusion when he writes:

Here we have, perhaps, the beginnings of an understanding of what we want visitors to leave, museums with—-the 'visitor take-aways' that alone can define the quality of the individual museum experience. Museums exist to enhance the quality of people’s lives, to satisfy their needs in every sensephysically, socially, intellectually, emotionally, spiritually: ‘museums are not simply places of enjoyment. They are places designed to uplift the spirit and enlighten the mind'. ${ }^{41}$ 
The application of education theory provides tools and resources, which allow the visitor to create their own meaning and personal narrative while viewing an exhibit. Phillip Black supports this view when he writes, "It really is possible to reflect learning theories directly in the exhibition process." ${ }^{\text {42 }}$ Black notes that educational theory alone is not enough to ensure that the needs of the visitor are being met. ${ }^{43}$ Museums must also take into consideration visitor's motivations, interests, expectations, prior experiences in museums, social and environmental needs, skills, as well as individual learning preferences and aptitudes.

The creation and implementation of the Jeunet exhibit allowed me the opportunity to incorporate educational theory as a means to encourage visitors to reflect on Jeunet's photographs as well as his personal writings and experiences. I tried to create a context that would encourage visitors to formulate questions, ponder issues, and provide ideas worthy of discussion. Educational and learning theory provided a lens that allowed me to see ways to facilitate the visitor's ability to find meaning and relevance among the aesthetics of Jeunet's photographs, his personal experiences and views, and the ability of photography to effectively communicate relevant social messages.

Ultimately, I felt the exhibit had served an important purpose. I was able, for the first time, to bring previously unknown photographs to a venue where visitors shared Jeunet's special gift as he looked beyond war and reaffirmed his choice for life. 


\section{ENDNOTES}

1 Keegan, John. (1998). The First World War. New York: Vintage. p. 282.

2 Ibid, p. 318.

3 Spalding, Richard and Cécile, editors. (2006). Jeunet, personal letters and journal entries. Unpublished translations by Richard and Cécile Spalding.

4 Ibid.

5 Serrell, Beverly. (1996). Exhibit Labels: An Interpretive Approach, Walnut Creek, CA:

AltaMira Press. p. 1.

6 Ibid, p. 6.

7 Richard and Cécile Spalding. (2006).

8 The Great War and the Shaping of the $20^{\text {th }}$ Century, http://www.pbs.org/greatwar/chapters/ch3_mutiny.html, “Mutiny.” Accessed March 3, 2007.

9 Richard and Cécile Spalding. (2006).

10 Carmichael, Jane. (1989). First World War Photographers, London and New York: Routledge. pp. 11-16.

11 Sikin, Jon, ed. (1981). The Penguin Book of First World War Poetry, New York: Penguin Books Ltd. p. 85.

12 Although All Quiet on the Western Front by Erich Maria Remarqueis one of the best known examples, an excellent resource that covers this subject in depth is The Cambridge 
Companion to the Literature of the First World War, edited by Vincent Sherry. 2005. I found the chapter titled "French Writings of the Great War” by Catharine Savage Brosman was particularly useful and insightful.

13 Bibliographies in Learning in the Museum, The Engaging Museum and references listed in Learning from Museums provide a broad overview regarding recent research and show the growing body of work in the field of museum education.

14 Silver, Harvey F., Richard W. Strong, Matthew J. Perini. (2000). So Each May Learn: Integrating Learning Styles and Multiple Intelligences, Association for Supervision and Curriculum Development. p. 8.

15 Darling-Hammond, Linda, Jim Rosso, Kim Austin, Suzanne Orcutt, and Daisy Martin. 2001. The Learning Classroom: Theory into Practice: A Telecourse for Teacher Education and Professional Development, Stanford University, pp. 32-33. 16 Black, Graham. (2005). The Engaging Museum: Developing Museums for Visitor Involvement, New York: Routledge, pp. 34-36.

17 Falk, J. H. and L. D. Dierking. (2000). Learning from Museums: Visitor Experiences and the Making of Meaning. Walnut Creek, CA, AltaMira Press. p. 139. 18 Newman, Robert P. (2004). Enola Gay and the Court of History, New York, NY: Peter Lang Publishing, Inc. pp. 97-133. (Since the controversy was so emotionally charged, readers might also reference Judgment at the Smithsonian, Philip Noble, ed. (1995). New York, NY: Marlowe \& Company. It contains the "complete, original, uncensored script” (p. xv) of the original exhibition to allow those interested to determine their own option regarding the controversy and the accuracy and integrity of the original script.) 
19 Esterow, Milton. (2005). “Get Out Your Handkerchiefs,” article in ARTnews, February, pp. 160 \& 158.

20 Falk, J. H. and L. D. Dierking. (2000). Learning from Museums: Visitor Experiences and the Making of Meaning, p. 149.

21 Ibid, p. 212.

22 Darling-Hammond, Linda, et al. (2001). p. 33.

23 Visual Understanding in Education. (2001). "Who is VUE?: VUE Background and History,” http://www.vue.org/whoisvue.html\#Background. Accessed June 3, 2007, and Visual Understanding in Education. (2001). "What is VTS: Part One,” and "What is VTS: Part Two What Schools Do.” http://www.vue.org/whatisvts2.html\#Whatschoolsdo. Accessed June 3, 2007.

24 Brock, Peter. (1968). Pacifism in the United States: From the Colonial Era to the First World War, NJ: Princeton University Press. (Brock’s book describes how in early American history pacifism initially was the work of individual religious movements; however, by the end of World War I it became international and ecumenical.) 25 Steffe, Leslie P., and Jerry Gale, editors. (1995). Constructivism in Education, NJ: Lawrence Erlbaum Associates. pp. 314-315.

26 Falk and Dierking, (2000). p. 182.

27 Falk and Dierking. (2000). p. 25.

28 Black. (2005). p. 5.

29 Ibid. p. 149.

30 Falk, Dierking. (2000). pp. 155-156.

31 Heine. (1998). p. 152. 
32 Falk \& Dierking. (2000). p. 201.

33 ASTC Dimensions, Journal of the Association of Science-Technology Centers. (2006). “Blogs, Podcasts and Wikis: Tapping the New Social Technologies,” July/August. 34 Lipscomb, G. B., Lisa Marie Guenther, Perry McLeod. (2007). “Sounds Good To Me: Using Digital Audio in the Social Studies Classroom.” Social Education 71(3): 120-124. 35 Ibid, pp. 120-121.

36 Risinger, C. F. (2006). "Using Blogs in the Classroom: A New Approach to Teaching Social Studies with the Internet.” Social Education 70(3): p. 130.

37 Historique de régiment de la grande Guerre 1914-18, “Histoire et Généalogie militaire,” http://www.docsources.org/categorie-40302.html, accessed March 2007. (Although written in French, I was able to use online translation software to piece together a crude translation of Jeunet's service record. Using the regimental numbers from his fellow soldier's uniforms, I found regimental histories for the $34^{\text {th }}$ Colonial Regiment and the $139^{\text {th }}$ Infantry and compared those histories to Jeunet's writings and the biographical notes provided by his family.)

38 Toon, Richard. (2005). "The Search for Learning Outcomes: Beyond the Deficit Model.” ASTC Dimensions. November/December 2005: pp. 11-12.

39 Heine. (1998). p. 139

40 Loomis, R. J., (1987). Vistor Evaluation: AASLH Management Series \#3, American Association for State and Local History. pp. 236-237.

41 Black. (2005). p. 286.

42 Ibid. p. 147.

43 Ibid. p. 149. 


\section{REFERENCES}

-----. (2005). ASTC Dimensions, Journal of the Association of Science-Technology

Centers. “Active and Engaged: Science Centers and Informal Learning,” November/December.

-----. (2006). ASTC Dimensions, Journal of the Association of Science-Technology Centers. "Blogs, Podcasts and Wikis: Tapping the New Social Technologies,” July/August.

Black, Graham. (2005). The Engaging Museum: Developing Museums for Visitor Involvement, New York: Routledge.

Brock, Peter. (1968). Pacifism in the United States: From the Colonial Era to the First World War, NJ: Princeton University Press.

Carmichael, Jane. (1989). First World War Photographers, London and New York: Routledge.

Darling-Hammond, Linda, Jim Rosso, Kim Austin, Suzanne Orcutt, and Daisy Martin. (2001). The Learning Classroom: Theory into Practice: A Telecourse for Teacher Education and Professional Development, Stanford University.

Esterow, Milton. (2005). “Get Out Your Handkerchiefs,” article in ARTnews, February, pp. $160 \& 158$.

Falk, J. H. and L. D. Dierking. (2000). Learning from Museums: Visitor Experiences and the Making of Meaning. Walnut Creek, CA, AltaMira Press. 
Falk, John H., and Lynn D. Dierking. (1992). The Museum Experience, Washington, DC: Howells House.

Falk, John H. and Beverly K. Sheppard. (2005). Thriving in the Knowledge Age: New Business Models for Museums and Other Cultural Institutions, Walnut Creek (CA): AltaMira Press.

Griffith, Paddy, illustrated by Peter Dennis. (2004). Fortifications of the Western Front 1914-18, Oxford: Osprey Publishing. 64 pp.

Hein, George E. (1998). Learning in the Museum, New York: Routledge. 203 pp.

-----. Historique de régiment de la grande Guerre 1914-18, “Histoire et Généalogie militaire,” http://www.docsources.org/categorie-40302.html, accessed March 2007.

Keegan, John. (1998). The First World War, New York: Vintage Press. 475 pp.

Lipscomb, G. B., Lisa Marie Guenther, Perry McLeod. (2007). “Sounds Good To Me: Using Digital Audio in the Social Studies Classroom.” Social Education 71(3): 120124.

Loomis, R. J. (1987). Vistor Evaluation: AASLH Management Series \#3, American Association for State and Local History.

Newman, Robert P. (2004). Enola Gay and the Court of History, New York, NY: Peter Lang Publishing, Inc.

Risinger, C. F. (2006). "Using Blogs in the Classroom: A New Approach to Teaching Social Studies with the Internet.” Social Education 70(3): 130-132.

Sefton-Green, Julian, editor. (1999). Young People, Creativity and New Technologies: The challenge of digital arts, New York: Routledge. 
Serrell, Beverly. (1996). Exhibit Labels: An Interpretive Approach, Walnut Creek, CA: AltaMira Press.

Silver, Harvey F., Richard W. Strong, Matthew J. Perini. (2000). So Each May Learn: Integrating Learning Styles and Multiple Intelligences, Association for Supervision and Curriculum Development.

Spalding, Richard and Cécile, editors. (2006). Jeunet, personal letters and journal entries. Unpublished translations by Richard and Cécile Spalding.

Sumner, Ian, illustrated by Gerry Embleton. (1995). The French Army: 1914-1918, Oxford, U.K: Osprey Publishing.

-----. The Great War and the Shaping of the $20^{\text {th }}$ Century, http://www.pbs.org/greatwar/chapters/ch3_overview.html, “Mutiny and Collapse.” Accessed March 3, 2007.

-----. The Great War and the Shaping of the $20^{\text {th }}$ Century, http://www.pbs.org/greatwar/chapters/ch3_mutiny.html, "Mutiny.” Accessed March 3, 2007.

Toon, Richard. (2005). “The Search for Learning Outcomes: Beyond the Deficit Model.” ASTC Dimensions. November/December 2005: 11-12.

-----. (2001). Visual Understanding in Education. "Who is VUE?: VUE Background and History,” http://www.vue.org/whoisvue.html\#Background. Accessed June 3, 2007. -----. (2001). Visual Understanding in Education. "What is VTS: Part One,” and "What is VTS: Part Two What Schools Do.” http://www.vue.org/whatisvts.html, http://www.vue.org/whatisvts2.html\#Whatschoolsdo. Accessed June 3, 2007. 
-----. War Letters, http://www.pbs.org/wgbh/amex/warletters/sfeature/sf_censorship.html, “Censorship.” Accessed June 10, 2007.

Yenawine, Philip. (1997). “Thoughts on Visual Literacy,” originally published in Handbook of Research on Teaching Literacy through the Communicative and Visual Arts, Ed. James Flood, Shirley Brice Heath, and Diane Lapp. Macmillan Library Reference. 


\section{APPENDICES}

\section{Appendix A1 - Handout: 10 Ways in Which World War I Still Affects Us Today}

\section{Ways in Which World War I Still Affects Us Today}

1) It changed the face of Europe and altered the balance of world power. Following World War I, the Allied powers (the United States, Great Britain, France \& Russia) divided Europe mostly along political and defensive lines.

2) It provided numerous advancements medical innovations. This same medical care continues to benefit both civilians and solders in the form of large-scale blood transfusions, artificial limbs, psychiatry, and facial reconstruction.

3) It led to the creation of most of the Middle East countries we know today.

4) It led to the use of a number of new military technologies (i.e., the machine gun, tank, zeppelin, chemical warfare).

5) It left a number of important geographic and political issues unresolved (e.g., the Balkans).

6) In the United States it enticed large numbers of African Americans to migrate from their mostly rural homes in the South in order to find factory jobs located in cities throughout the North and Northeast.

7) It established the United States as a premiere international entity.

8) It led to new momentum in drawing attention to the suffragette movement and women's rights.

9) The modern pacifist movement grew out of reaction to World War I.

10) The League of Nations is created eventually leading to the United Nations and the idea of a worldwide diplomatic body working to promote international security. 


\section{Appendix A2 - Handout: History of Pacifism in the U.S.}

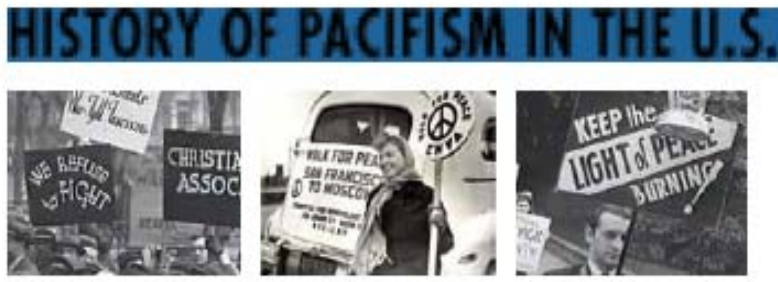

Conscientious objection has a unique place in United States history. In fact, the tradition of refusing military service - and the recognition of that right - can be traced back to America's founding fathers, some of whom were pacifsts fleeing oppression for their beliefs in Europe. Several of the original colonies, including Pennsylvania, Delaware and New Jersey, were founded by the Quaker pacifist William Penn.

The framers of the U.S. Const tution even considered including an exemption from military service for conscientious objectors in the Second Amendment. This clause was omitted because they did not envision the need for creating a standing army.

At the onset of the Revolutionary War, George Washington issued a draft order, which was a cal to "all young men of suitable age to be drafted, except those with conscientious scruples against war."

During the American Civil War, the conscription law of the North provided the opportunity for religious objectors and others to buy their way out of the draft. Those who refused or could not afford that option were treated harshly under military law. Four thousand men served in the military as unarmed legal conscientious objectors (COs).

World War I ushered in the first draft since the Civil War, and policies that were even less tolerant of conscientious objectors. Seventeen draft resisters died of mistreatment in Alcatraz Prison during World War I.

In World War II, a total of nearly 43,000 Americans refused to fight for reasons of conscience: 12,000 served in Civilian Public Service, 6,000 went to prison and 25,000 served in the military as noncombatants. During the Vietnam War more than 170,000 men were olficially recognized as conscientious objectors. Thousands of other young men resisted by burning their draft cards, serving jail sentences, or leaving the country.

Though the military is currently an all-volunteer organization, when the Gulf War broke out in 1991, 2,500 men and women volunteers serving in the Armed Forces refused to serve in Saudi Arabia on the basis of conscience. While draft ooposition has been an individual decision

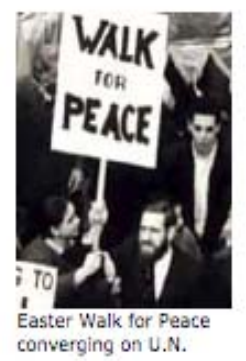
made by a minority in all U.S. wars, public opposition to wars such as the War of 1812 , the Mexican War, World War I and the Vietnam War sparked mass movements that reached far beyond men of draft age.

Informaton from PQS website, http://www.sbs.arg/itys/thegootwat/american pacilim.thtrl. All photes on this page courtesy of the War Resisters Leaçue. 


\section{Appendix A3 - Handout: Excerpts from Jeunet’s diaries and letters}

\section{Excerpts from Jeunet's diaries and correspondence, translated by Richard and Cécile Spalding:}

1915, Autun, France, training station, prior to service on the Western front. This is an excerpt from a note written July 5, 1915 to his first cousin, Jean Jeunet.

...we are also digging trenches, day and night, with simulated attacks and we fire salvos only during the night. So...that is that! Les boches [the Germans] had better watch out. I am well and am suffering neither from lack of food or from fatigue. If you could only see the great gamelles [mess kits] I eat every day! without counting the desserts [sent by family members]. After all, I would be happy, if the absence of my dear parents didn't weigh so heavily. I do get their good and frequent letters, but that is not enough. And to think that we don't even get passes to go to see them! Just the same I hope to get to Paris before leaving for the front.

1952, Paris, France, from a letter written on January 27,1952 to his daughter and sonin-law, prior to his and Mme. Jeunet's visit via ocean liner to the United States.

I think that I will not be sea-sick on the trip because I was not [sick] in 1917 during the night crossing of the Adriatic Sea in bad weather on a small ship, the Château-Renault, weighing hardly 15,000 tons. What is more, there was that terrible fear of the submarines, which didn't help matters! The ship behind ours was torpedoed in the Gulf of Corinth and sank. No victims other than the mechanics killed by the explosion of the torpedo in the machine room, and in addition, the rescued persons got a one month leave of absence. I wasn't so lucky....if you can call it that!

1954, Paris, France, from a letter written on August 19, 1954 to his daughter and sonin-law.

My greatest act of gratitude remains having endured, during four years of World War I, that unspeakable horror! It was there that the spirit of the seeker and the idealist was strengthened in me, a spirit that could be born solely out of a great misery suffered in common with others, and I have knowingly not limited them to my countrymen. 
Appendix A3 (cont.) - Handout: Excerpts from Jeunet’s diaries and letters

\section{Excerpts from Jeunet's diaries and correspondence, translated by Richard and Cécile Spalding:}

1940, Tournus, France, letter to his father, Emile, in Paris, after France's defeat. Captured by the Germans in southern France, he was released immediately.

Mon cher Papa, October 7, 1940, Tournus, France

My Dear Papa,

Here I am at last. Take heart! I am returning, at my own slow pace, by bicycle from Lyon. I will also see, on my way, the Pions in Chambolle, the Baillons in St. Aubin, and Jean in Melun. All is well so far, and I believe I can be with you at the end of this week.

I hope to find you cheerful, and in good health, just as I left you at the beginning of last June, already four months. Four months during which so much has happened. You can really say that you have witnessed a lot in your lifetime! Do you remember Jules Roux: "old as we are, still we have never seen that!" Now, this time, he can truthfully say it, the poor fellow.

Oh well, even if I will be without a job after this "brawl", I am, just the same, damn glad to get back to all of you, and to return to my family life in our lovely rue Gros.

You will surely have a lot to tell me-almost as much as I to tell you.

Au revoir, dear Papa, and be patient. Very soon we can embrace each other as before...during the good old times when there was peace. Je t'embrasse affectueusement et à bientôt. André 
Appendix A4 - Handout: WWI Resource Guide

\section{To learn more about "The Great War" check out the following resources:}

\section{Books:}

American Heritage History of World War I

Random House Value Publishing (July 16, 1988)

ISBN: 0517385554

The Guns of August, Barbara Tuchman

Ballantine Books; Reprint edition (March 8, 1994)

ISBN: $034538623 \mathrm{X}$

The Price of Glory: Verdun 1916, Alistair Horne

Penguin (Non-Classics); Reissue edition (January 1, 1994)

ISBN: 0140170413

Death of a Generation: From Neuve Chapelle to Verdun and the Somme

Alistair Horne

McGraw-Hill (January 1970)

ISBN: 0070303479

The First World War, John Keegan

Vintage Books (May 16, 2000)

ISBN: 0375700455

The First World War, Hew Strachan

ISBN: 0670032956

Forgotten Voices of the Great War: A History of World War I in the Words of the Men and Women Who Were There, Max Arthur

The Lyons Press (November 1, 2004)

ISBN: 1592285708

The First World War : Germany and Austria-Hungary 1914-1918, Holger H. Herwig A Hodder Arnold Publication (November 29, 1996)

ISBN: 0340573481

Birds Without Wings (historical fiction), Louis De Bernieres

Knopf (August 24, 2004)

ISBN: 1400043417

All Quiet on the Western Front (historical fiction), Erich Maria Remarque Ballantine Books; Reissue edition (March 12, 1987)

ISBN: 0449213943 
Appendix A4 (cont.) - Handout: WWI Resource Guide

\title{
Books:
}

Johnny Got His Gun (historical fiction), Dalton Trumbo Citadel Press; Reprint edition (November 1994)

ISBN: 0806512814

\section{Movies \& Videos:}

The Great War and the Shaping of the $20^{\text {th }}$ Century, PBS http://www.pbs.org/greatwar/about/

A Very Long Engagement, Warner Home Video

Director: Jean-Pierre Jeunet

All Quiet on the Western Front (1930), Universal Studios Director: Lewis Milestone

Gallipoli (1981), Paramont

Director: Peter Weir

\section{Websites:}

\author{
http://www.bbc.co.uk/history/war/wwone \\ http://www.fordham.edu/halsall/mod/modsbook38.html \\ http://www.pbs.org/greatwar/chapters/index.html \\ http://firstworldwar.com
}

Please Do Not Remove from Gallery 


\section{Appendix 2 - Handout: The Kodak Folding Camera}

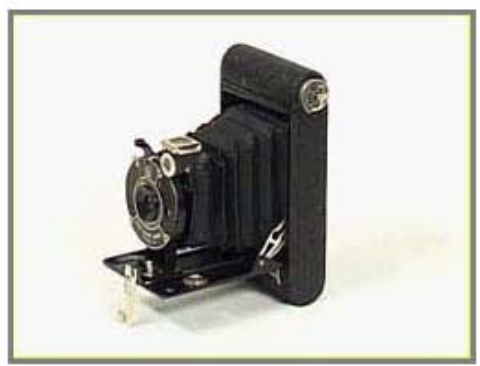

\section{The Kodak Vest Pocket Camera}

Introduced in 1912, the original Kodak "Vest Pocket" Camera represented "breakthrough technology" for its day. The pocket-sized folding camera looked almost exactly like the larger folding Kodaks but used a new small film size. The little rolls of film yielded eight $15 / 8^{\prime \prime} \times 21 / 2$ " exposures each-large enough to make contact prints but small enough to keep the camera palm-sized. The socalled "miniature" camera first retailed at $\$ 6.00$-far less than the larger folding models - and became popular with soldiers during World War One.

The "Vest Pocket Model B," which Mallory used on Everest, was introduced in 1924, and included several new design features. One of the most significant was the "autographic" window on the camera back. By sliding a small door open, the photographer was able to inscribe some information about the picture through the backing paper, directly onto the film-a distant ancestor to today's "day $/$ date" modes in some electronic cameras. Improvements were also made in rollloading by making the entire front of the camera removable

No century has been so thoroughly documented as the one we are about to exit. By 1924 the small camera, often a folding model, was a fixture in homes worldwide, finding most of its function on vacations and picnics, beaches, and similar idyllic sunny days. The little Vest Pocket Kodak Model B that found itself slowly ascending the treacherous slopes of Mt. Everest had a somewhat more important task. Loaded with "NC," or Non-Curling black-and-white film, it was a compact recorder of the destiny of the ill-fated expedition. Despite the proliferation of the word "digital" to describe everything from television to toothpaste, black-and-white photography, in its elegant simplicity, has required few new innovations to create images.

If this 1924 film, missing for three quarters of a century, is found, some interesting measures will be taken to recover any images that may be present on the narrow rolls 


\section{Appendix 2 - Handout: The Kodak Folding Camera}

\section{The Kodak Vest Pocket Camera, cont.}

According to one of us (Bob Strickland, a Kodak Photographic Expert for over 30 years), the recommendations for the priceless film include keeping it frozen until just before development, thus preserving its physical state. Secondly, a small snipping of the roll's end should be taken in total darkness and processed to determine the exposure and type of images recorded on the film. Processing solutions should likely be kept at temperatures of no more than 70 degrees, with a reduced-activity developer to minimize image "grain." As a result, longer developing times must be used.

While these are strictly recommendations only, preliminary experiments on the small end cuttings will reveal the effects of the developing tests. Although the film was, by nature, blue-light-sensitive only, the use of a safelight is not recommended, given the danger of adding fog to the film's emulsion.

If they find the film, the answer to one of the century's greatest mysteries may very well be told by a humble, pocket-sized Kodak.

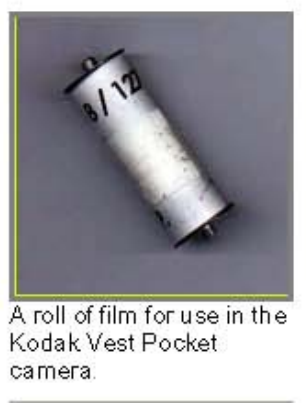

By Steve Garfinkel and Bob Strickland

Photos: (1) Peace River Studios; (2) NOVANGBH.

Taken in incomplete form from the PBSNNova website Lost On Everest: http / /www pbs.orghwgbh/novaleverest/lost'search/camera.html, accessed April 2006. 


\section{Appendix B1-Exhibit Panels: Jeunet Bio Panel}

\section{A BRIEF BIOGRAPHY}

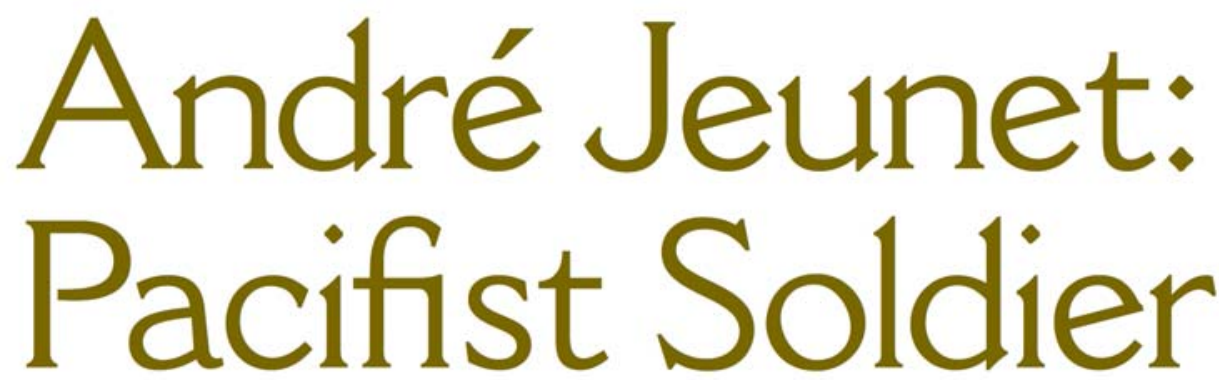

André Jeunet was born September 20, 1896 in Bourg-la-Reine, France, a suburb south of Paris. He was an idealist, a philosopher, a dreamer with a passionate love for the lively arts - his admiration

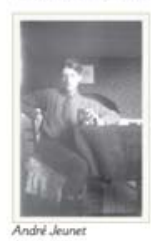

for Beethoven and

Goethe was unlimited.

As a pacifist soldier

during la Grande Guerre,

he, with but a few

exceptions, turned the

lens of his Vest Pocket

Kodak away from the

violence and horrors of battle.

With the sure instincts of the artist, he focused instead on the events of the every-day military life, scenes of troop movements and leisure activities, the countryside, the villages and the people he encountered. There is no record of any censorship by his commanders.

Jeunet's unique images of the Great War present a carefully composed look at scenes seldom portrayed in World War I retrospectives. Those in this exhibit represent but a fraction of his 205 negatives now held in the Special Collections of the Photographic Archives at the University of Louisville.

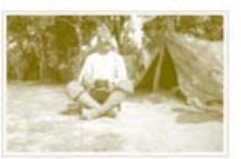

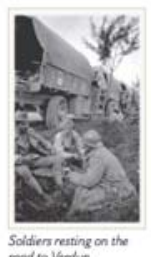

In March, 1915, at age 18 , Jeunet was inducted into the French army. He served on the French Western Front and on the Eastern Front in the Balkans. Jeunet knew sodictiondin the agony of warfare in the front line trenches

but, other than contracting malaria during his eastern stint, he suffered no injuries and maintained good health throughout the four years.

He steadfastly refused promotions. retaining the rank of private. Whenever possible, he sought to isolate himself from the stress of army life, finding solace in observing the rural sites and filling his diary with reflections on life.

On April 4, 1919, in Rasczabanya, he was "showered and deloused for the last time," declared répatriable" (and) "carried no more trace of

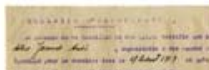
Itor $=$ (1) vermin." He was Jeunet's delowaing certififoate discharged April 26, 1919.

Following his discharge, Jeunet returned to Paris and became a student of art and architecture. In 1921, he married Aimée Révil-Signorat, and their daughter, Cécile, was born in 1924.
In October 1939, a practicing architect, a veteran of "1914" with a wife and daughter, he was again drafted into the French army. After France's defeat he returned to his family in Paris, undergoing the hardships of four years of German occupation.

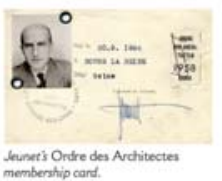

In 1945, Jeunet's daughter Cécile met native Louisvillian, Richard Spalding, during his service in France with the U.S. Air Force. Spalding returned to France in 1948 to study music and they were married in Paris that November. In 1949, the Spaldings settled in Louisville, Kentucky.

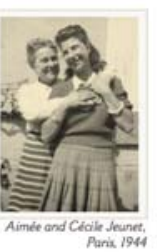

Following a summer visit to the USA in 1952, André Jeunet discovered that l'Amérique was the "country of my dreams." He and Mme. Jeunet immigrated to the United States in 1958. He worked for several architectural firms in Louisville from 1960 to 1970.

Far removed from the war-torn turmoil of his youth, he enjoyed his later years in gentle comfort, surrounded by his family until his death on September 3 , 1979. 


\section{Appendix B2-Exhibit Panels: World War I Historical Overview}

HISTORICAL OVERVIEW

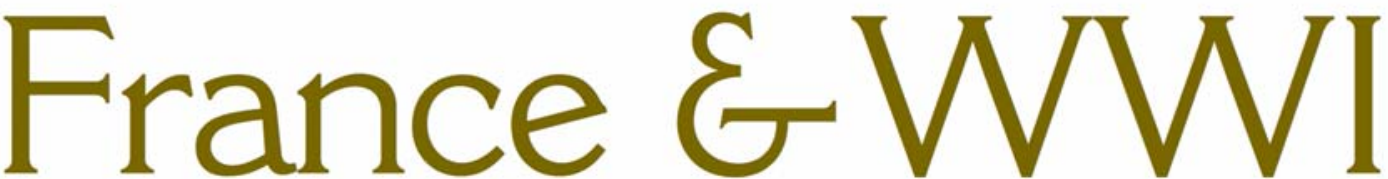

In the mid-1860s France was considered the most powerful state in Europe. In 1859 it had twice defeated the armies of the Austro-Hungarian Empire. Yet only seven years later, in July of 1870 , Prussia, led by chief minister Otto von Bismark, would provoke the French into declaring war. The French were quickly outmaneuvered and in a humiliating defeat Paris found itself under siege. By May 1871 with the signing of the Treaty of Frankfurt, France had surrendered the provinces of Alsace and Lorraine to a newly unified German Empire that would quickly change the balance of power in Europe.

These conflicts aggravated long-standing suspicions between France and Germany and led to a series of political and military alliances that would fuel tensions throughout Europe through the end of the $19^{\text {th }}$ and into the early $20^{\text {th }}$ century.
Competition for colonial, economic, and military domination also encouraged the potential for conflict.

In addition to views of the trenches that stretched across Europe, many of the pictures in this exhibit include images of the villagers and landscapes of the Balkan States. The rise of nationalistic fervor in the region, political instability, and the desire for independence from the AustroHungarian Empire and Ottoman Turkey led the area to be called the "tinderbox"

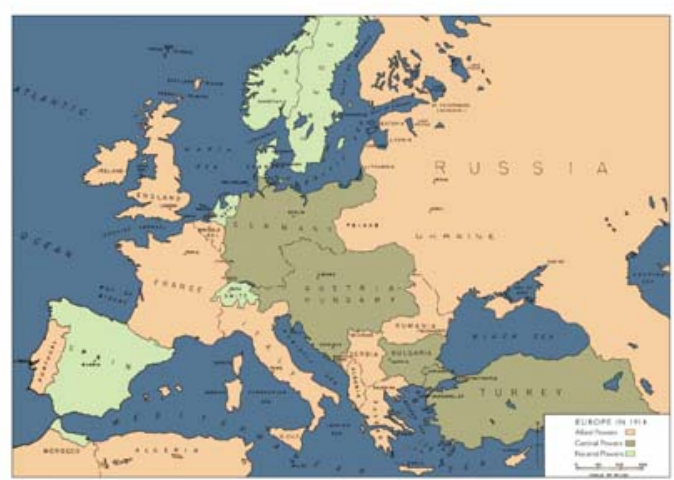

which started World War I.

Archduke Franz Ferdinand, the heir to the throne of the AustroHungarian Empire, and his wife visited Sarajevo in June 1914, where they were killed by Serbian assassins opposed to Austrian expansion in the Balkans. The assassinations resulted in Austria's declaration of war on Serbia and triggered a series of alliances that drew much of Europe into the war within a few weeks. The Kingdom of Serbia called on Russia for support, while the AustroHungarians turned to Germany. Planning that France would hold its alliance with Russia, the Germans attacked France through Belgium, an act which drew Great Britain to the Allied side. Most of Europe and Ottoman Turkey would be drawn into the war in the succeeding months. The United States would end up joining the Allies, but not until 1917 .

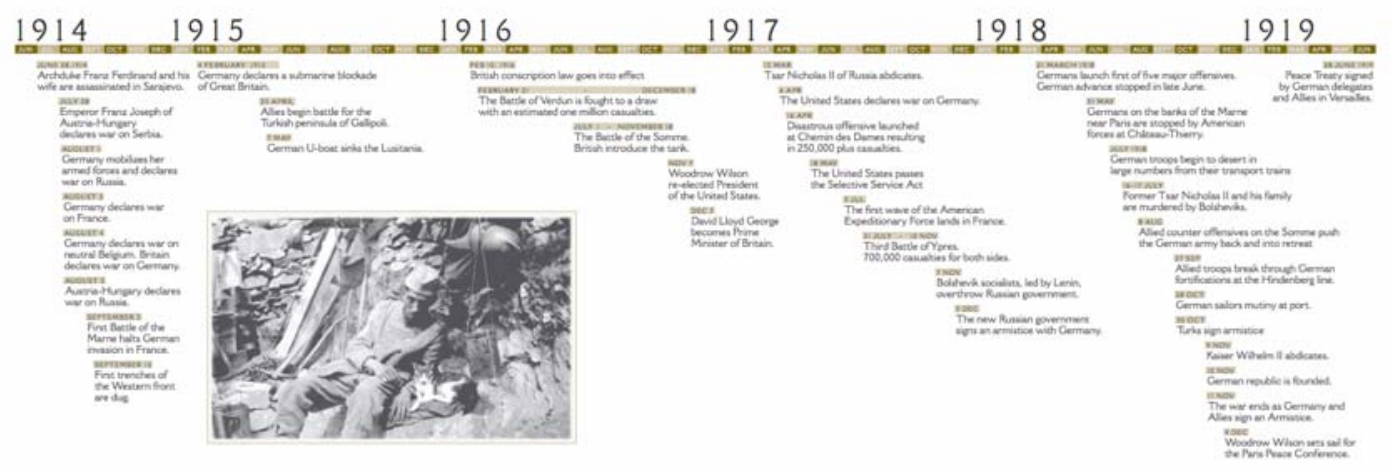


Appendix B3-Exhibit Panels: Jeunet Personal Writings Excerpts

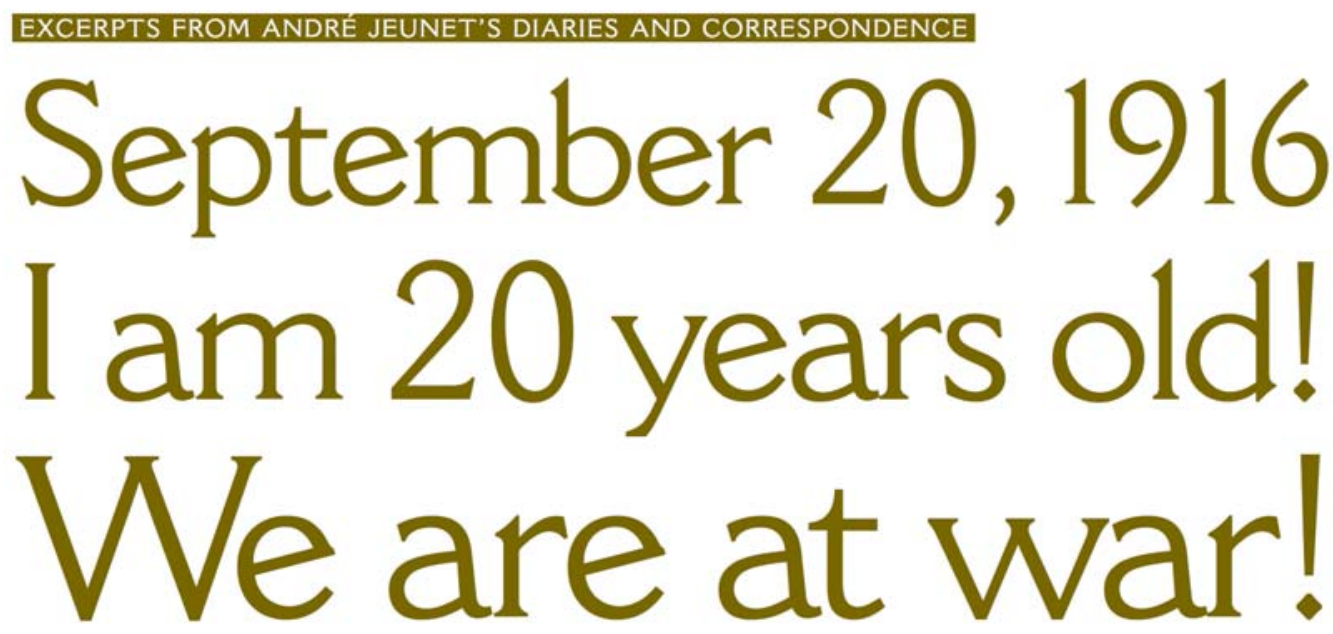

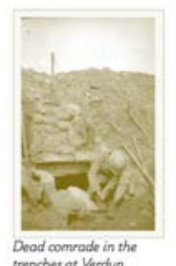

Andre Jeunet recopied hia World War 1 dary entry from September 20, 1916 (Weunets $20^{\circ}$ birthday) witha 1944

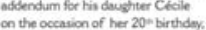
Septenter 16, 1944.

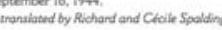

September 20, 1916. I am 20 years old! We are at war! The 'Great

War' as future historians will say and before its crown will be toppled by the next 'last war'.

We are approaching the end of the famous battle of the Somme, where I risked my life, while I was playing my sad role of infantry man at Chaulnes, a pitiful town, reduced to a few piles of rubble, surrounded by dead trees, branchless as frightful skeleton-like masts of ships, sunken and stuck in this sea of mud, which, in the nearby craters, opened by thousands of shell bursts, forms an unmoving swell.

I am 20 years old! And one cannot perceive the end of the massacre which has already lasted two years.

I am 20 years old and have only before my eyes the horrible spectacle of death. No more leaves, no more flowers, no more animals, even no more grass on the soil...this hilly and muddy ocean engulfs everything-even our souls, without light, and without joy.

September 16,1916 ! I am 20 years old, but my body is covered with vermin and my spirit is eaten by doubts.
Sixteenth of September 1944 ! Cécile is twenty years old! No more mud, nor lice, but the joyful spring-like parade of bright young friends, gifts, finery, talent, dresses... all illusion!

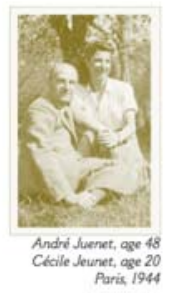

...For, once again we are at war - entire cities crumble and rain fire on the throngs of innocent mothers and children. My heart is weary to have to write here this bitter preface to a text, older than my daughter by a quarter of a century!"

Paris, September 1944

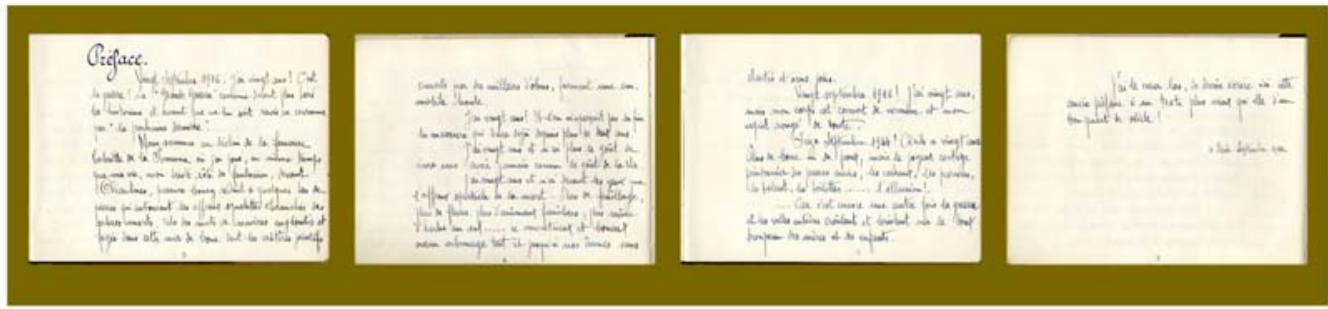


Appendix B4: Exhibit Title

André Jeunet: Images of World War I by a Pacifist Soldier

Appendix B5: Donor Panel

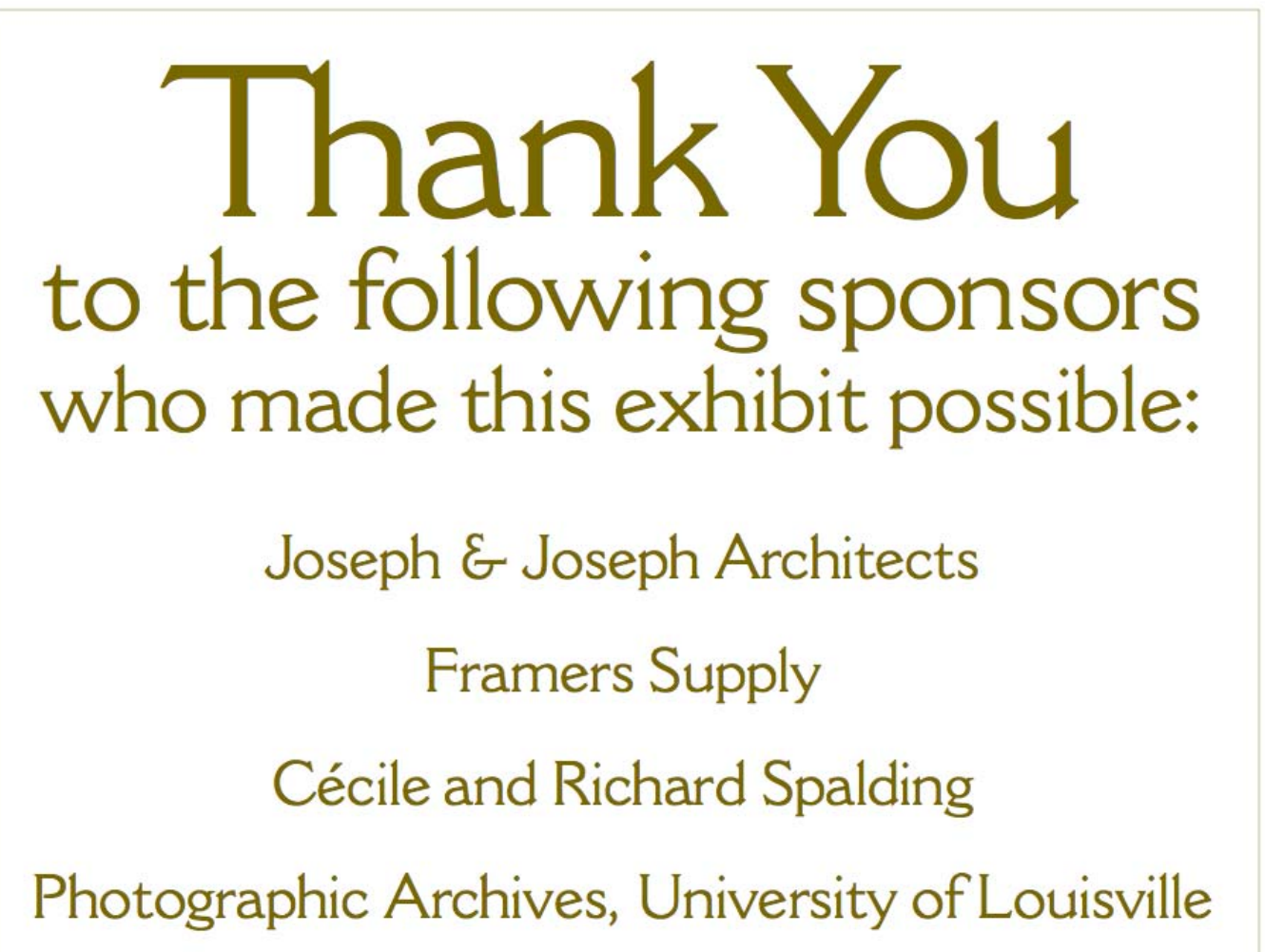


Appendix C1 - Exhibit Photographs
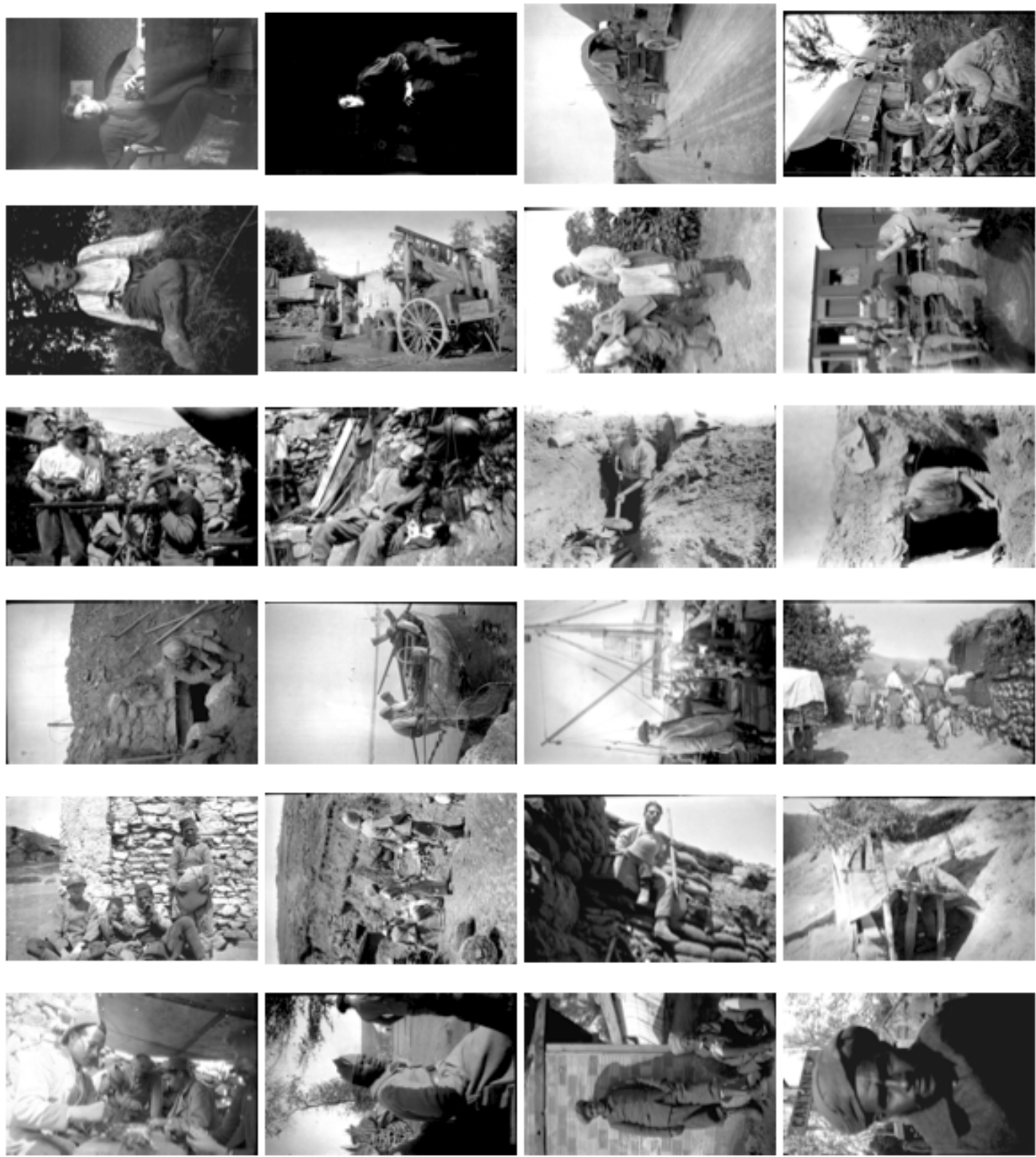

SOURCE: André Jeunet Collection, Special Collections Photographic Archives, University of Louisville. 
Appendix C1- Exhibit Photographs
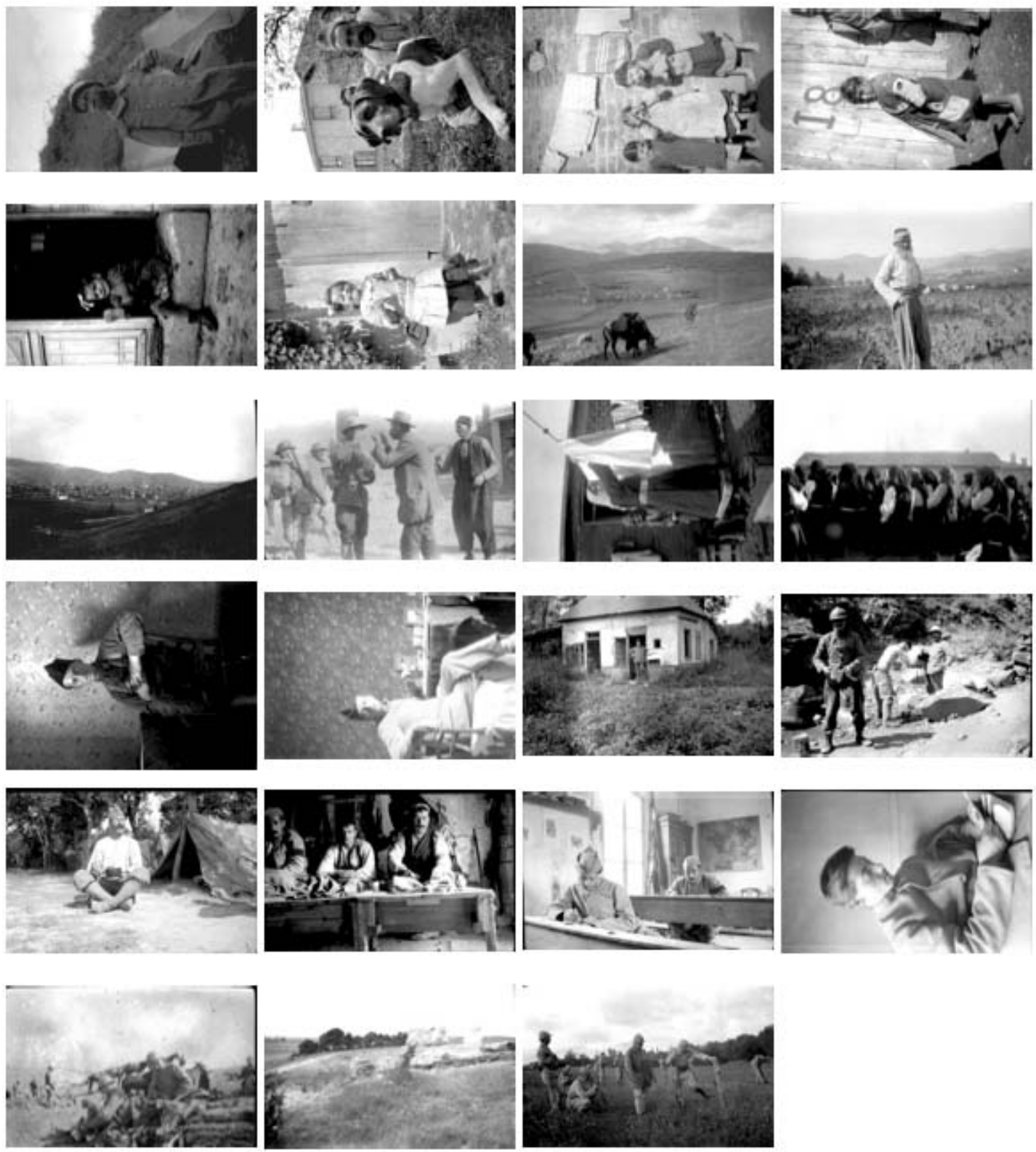

SOURCE: André Jeunet Collection, Special Collections Photographic Archives, University of Louisville. 
Appendix C2- Exhibit Layout

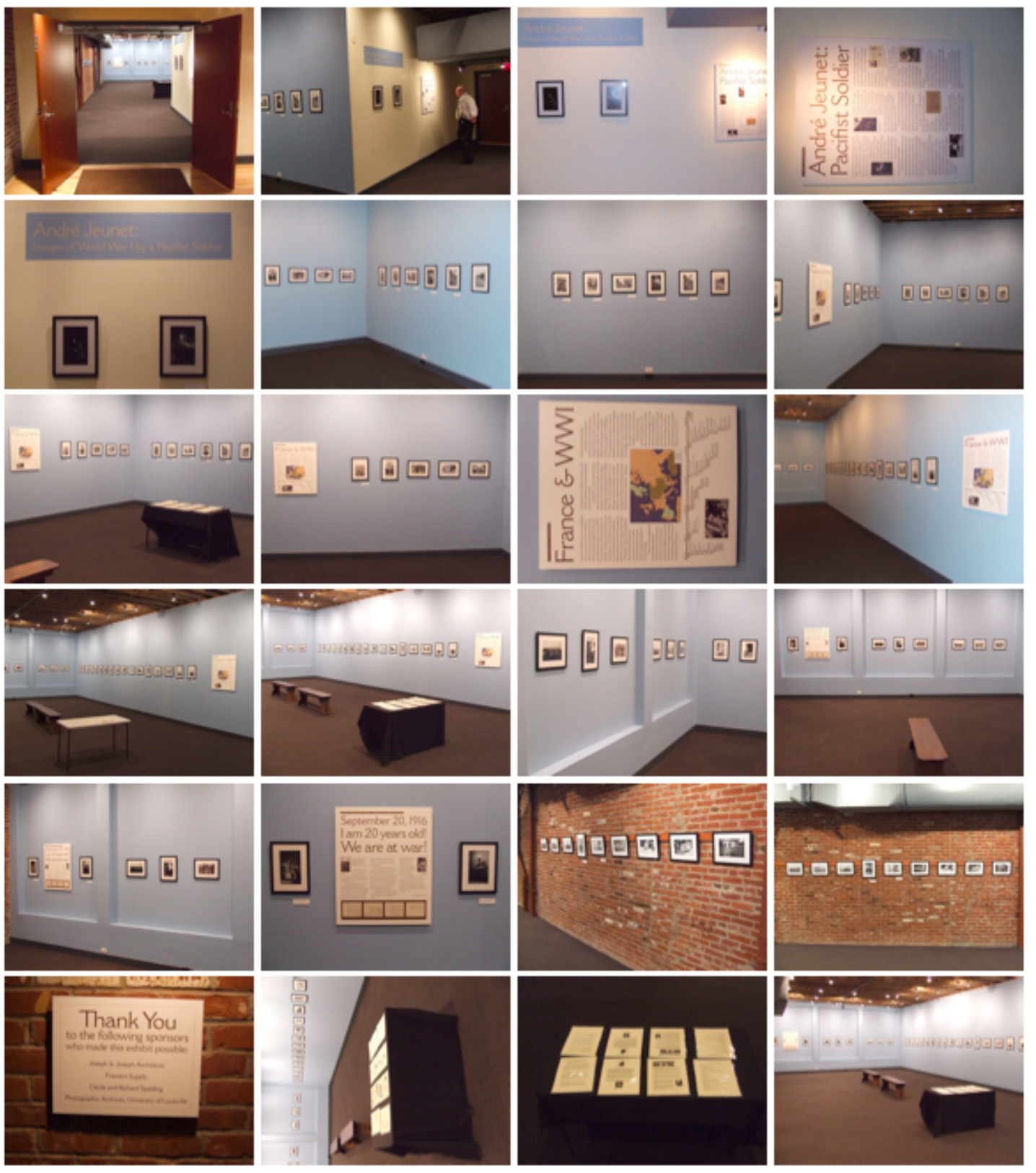

SOURCE: Photographs by author. 
Appendix C3 - Exhibit Opening Reception
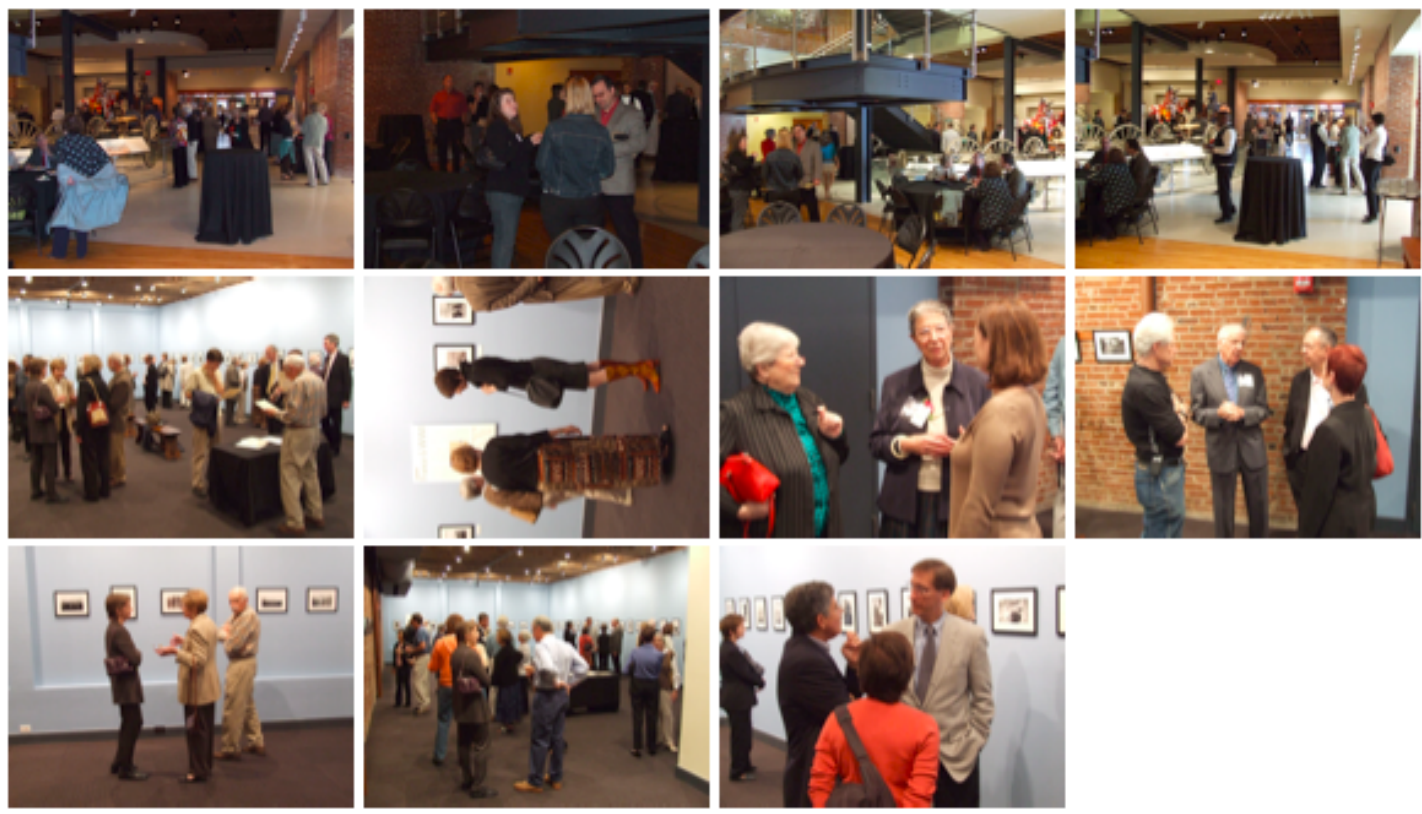

SOURCE: Photographs by author. 
Appendix D1 - Exhibit Article Louisville Magazine August 2006

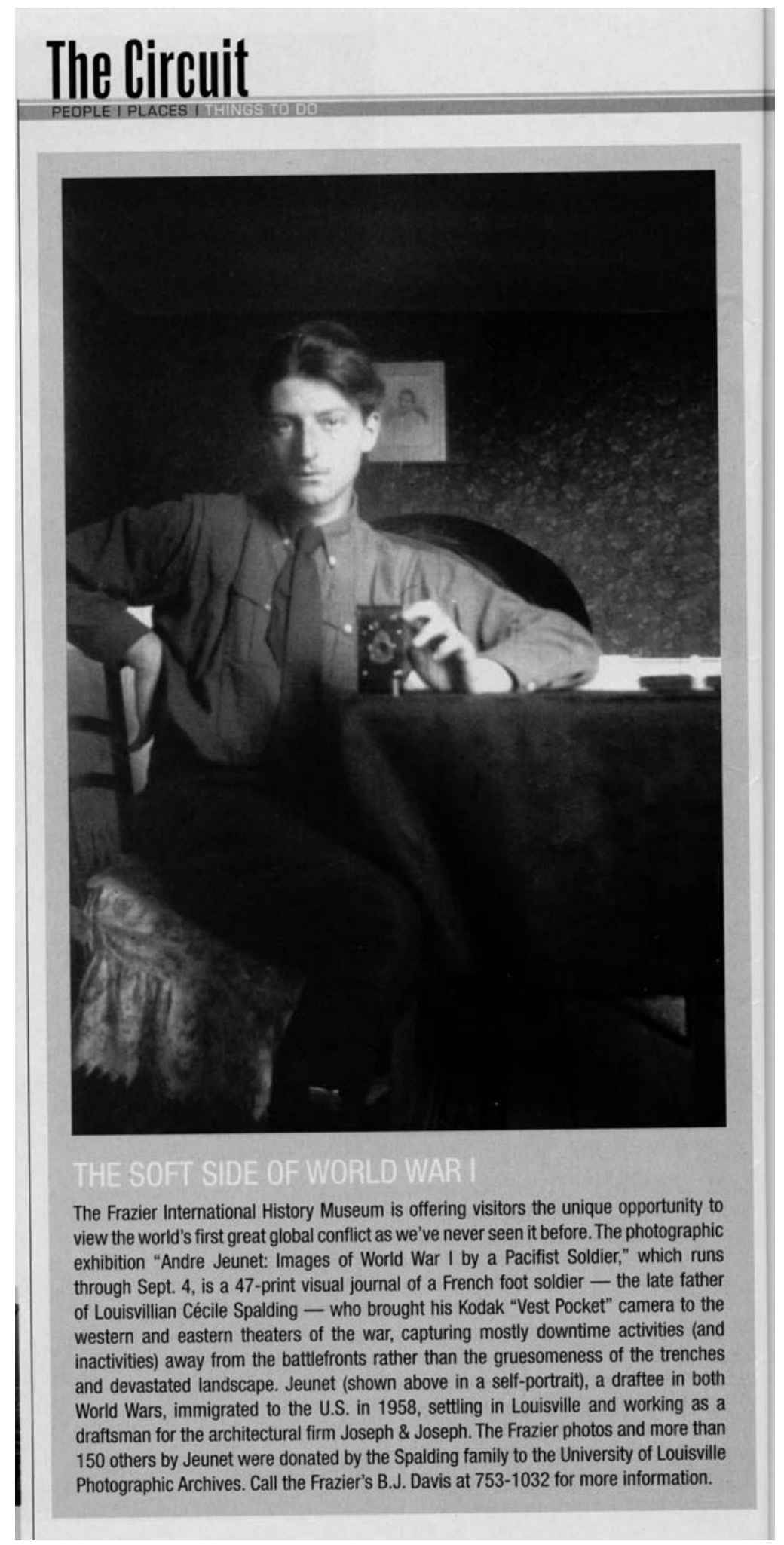


Appendix D2 - Postcard Announcing Exhibit Opening

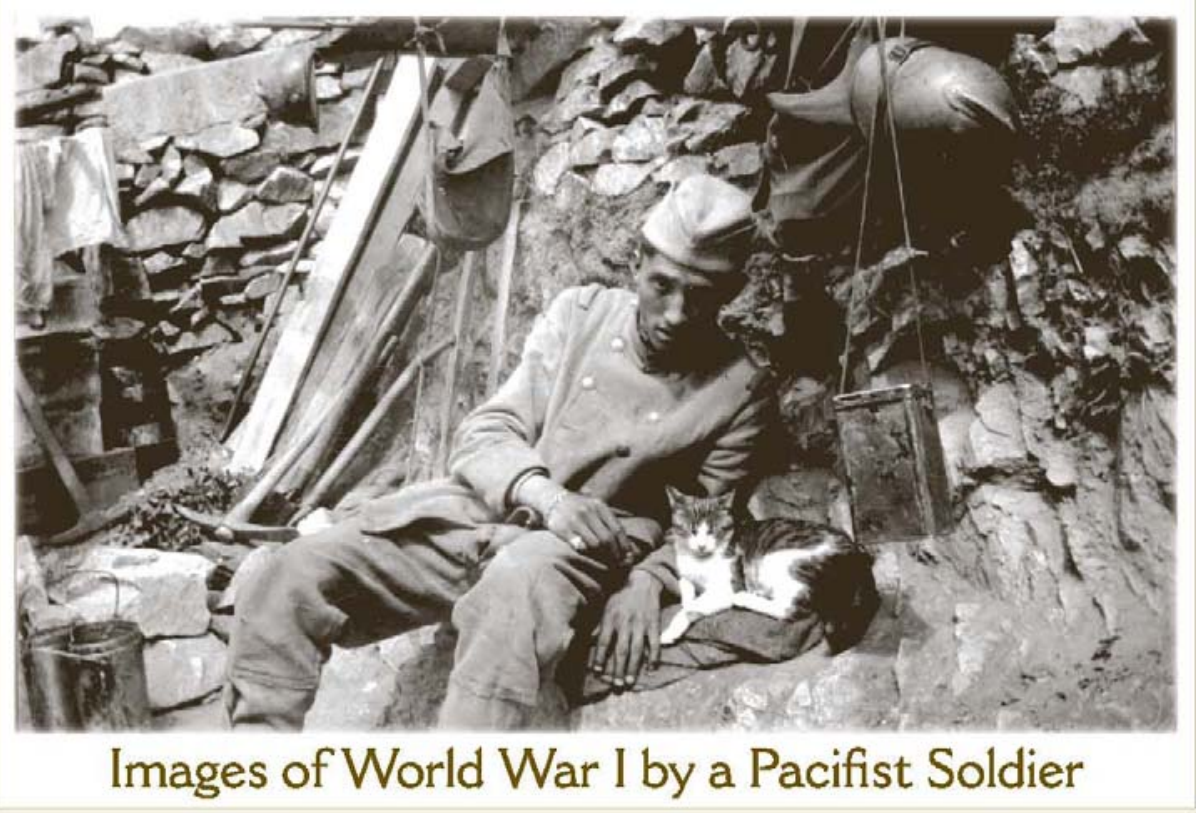

André Jeunet:

Images of World War I by a Pacifist Soldier

A selection of photographs from 1914-1918

Opening reception:

Thursday, May 18

5:30-8:30 pm

May 19 -September 4, 2006

Frazier Museum

829 West Main Street

Sponsored by:

Joseph \& Joseph Architects

Framer's Supply

Richard and Cécile Spalding

Photographic Archives, University of Louisville

Non-Profit Org U.S. Postage

PAID

Louisville, KY

Permit No. 1111

\section{FRAZIER}

Historical Arms MUSEUM

829 West Main Street

Louisville, KY 40202 
Appendix D3—Exhibit Press Release

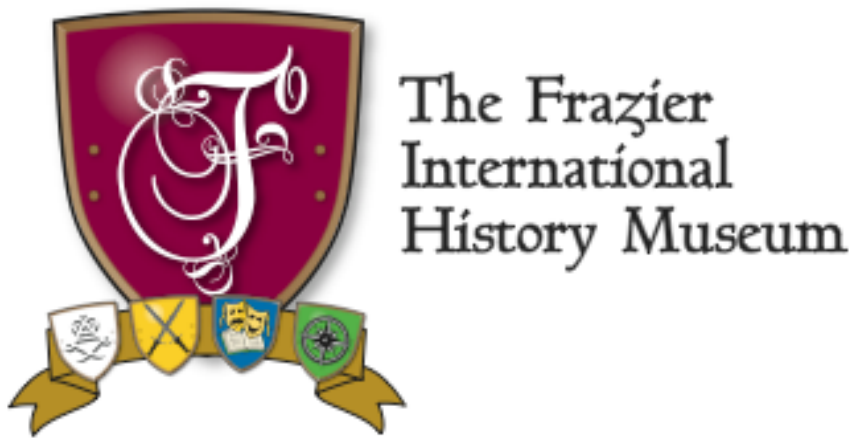

FOR IMMEDIATE RELEASE:

FOR MORE INFORMATION:

May 17, 2006

Susan McNeese Lynch

(502) 836-5347

smlcomm@aol.com

Michelle Gelback

(502) 753-1681

mgelback@fraziermuseum.org

\section{FRAZIER INTERNATIONAL HISTORY MUSEUM ANNOUNCES THE OPENING OF A NEW EXHIBITION:}

\section{André Jeunet: Images of WWI by a Pacifist Soldier}

Louisville, KY - The Frazier International History Museum announces the opening of a new exhibition André Jeunet: Images of WWI by a Pacifist Soldier. The exhibition will open on Friday, May 19 and continue through Monday, September 4.

The exhibit, made possible by the Frazier International History Museum in conjunction with the University of Louisville Photographic Archives, is the first public exhibition consisting of 47 photographs taken by André Jeunet during World War I. Jeunet captured over 200 images of the war depicting everyday life as a foot soldier and documenting his travels in France and the Balkans as part of the Salonika campaign. Later, he was drafted and served in the French army during WWII before immigrating to the United States in 1958 and settling in Louisville. The 205 surviving WWI negatives were donated to the University of Louisville Photographic Archives by his daughter and son-in-law, Cécile and Richard Spalding. 
Jeunet/Page Two

Carrying his folding camera and photographic film with him during the entire war, Jeunet captured an uncensored insider's look at war. Serving in the infantry during 'La Grande Guerre,' Jeunet, for the most part, turned his lens away from the violence and horrors of war. An idealist, philosopher, and a dreamer with a passionate love of the arts, he focused instead on the events of every-day military life, scenes of troop movements and leisure activities, the countryside, and the villages and people he encountered. Witnessing the devastation and waste of war at a young age made a profound and lifelong impact on Jeunet.

The exhibition is made possible through the generosity of: Joseph and Joseph Architects, Framers Supply, Cécile and Richard Spalding, and the University of Louisville Photographic Archives.

For more details and information, check our website at www.fraziermuseum.org.

$$
\text { \#\#\# }
$$

The Frazier International History Museum

In collaboration with the Royal Armouries (Britain's oldest national museum), The Frazier International History Museum covers 1,000 years of history. The priceless collection is housed in a 100,000 square foot, state-of-the-art museum in downtown Louisville's historic Doerhoefer building. The Frazier brings history to life every day through live interpretations by costumed interpreters, multimedia presentations, educational programming and hands-on learning. The Frazier International History Museum is the only museum to have a partnership with the Royal Armouries, making it the only museum of its kind in the United States and the world. For more information about the Museum, please call (502) 412-2280 or go to www.fraziermuseum.org. 


\section{CURRICULUM VITAE}

NAME:

ADDRESS:

DOB:

EDUCATION

\& TRAINING
Brian Jeffrey Davis

North Carolina Museum of History

Education Section

5 East Edenton St

Raleigh, NC 27699-4650

Louisville, Kentucky - December 1, 1958

B.A., Urban Studies

Ohio Wesleyan University

1976-1979

A.A., Music Performance (Guitar)

Jefferson Community College, University of Kentucky 1982-1984

National Museum of American History

Smithsonian Institution

Program Specialist

1986-1994

Frazier International History Museum

Head of Education

2003-2007

North Carolina Museum of History

Education Section Chief

2007-Present

AWARDS:

Alumni of the Year

Jefferson Community College

1996

PROFESSIONAL SOCIETIES:
Museum Education Roundtable

EdCom, American Association of Museums

National Council for History Education 
INVITED

PRESENTATIONS: Spalding University, Louisville, KY

Liberal Studies Department

Keynote Speaker, Departmental Graduation Awards Ceremony

2004, 2005, 2006

Association of Science and Technical Centers

Annual Conference, Louisville, KY,

October 29, 2006

Teacher Programs in an Age of Educational Accountability

Panelist 